\title{
Ionic liquids as an additive in fully formulated wind turbine gearbox oils
}

\author{
R. Monge ${ }^{\mathrm{a}}, \mathrm{R}$. González ${ }^{\mathrm{b}, \mathrm{e}, *}, \mathrm{~A}$. Hernández Battez ${ }^{\mathrm{c}, \mathrm{e}}$ \\ A. Fernández-González ${ }^{\mathrm{d}}$, J.L. Viesca ${ }^{\mathrm{c}, \mathrm{e}}$, A. García ${ }^{\mathrm{c}}$, M. Hadfield ${ }^{\mathrm{e}}$ \\ ${ }^{\text {a }}$ Engineering Division, CELLS - ALBA Synchrotron Light Facility, Barcelona, Spain \\ ${ }^{\mathrm{b}}$ Department of Marine Science and Technology, University of Oviedo, Asturias, Spain \\ ${ }^{\mathrm{c}}$ Department of Construction and Manufacturing Engineering, University of Oviedo, Asturias, Spain \\ ${ }^{\mathrm{d}}$ Department of Physical and Analytical Chemistry, University of Oviedo, Asturias, Spain \\ ${ }^{\mathfrak{e}}$ Faculty of Science and Technology, Bournemouth University, UK \\ ${ }^{(*)}$ Email: gonzalezrruben@ uniovi.es
}

\begin{abstract}
This work presents the friction and wear behaviour of two fully formulated (polyalphaolefin- and mineral-based) wind turbine gearbox oils separately additivated with two ionic liquids ([Choline][NTf $\left.{ }_{2}\right]$ and $\left.[\mathrm{BMP}]\left[\mathrm{NTf}_{2}\right]\right)$ at $5 \mathrm{wt} \%$ concentration. A tribometer using a ball-on-plate reciprocating configuration is adopted for friction and wear experiments. Friction is measured during tests and the worn surface is measured and analysed by confocal microscopy, SEM, EDS and XPS. The friction and wear results show that both ionic liquids used as an additive have a slight friction modifier character but a strong wear reducing performance, with [BMP][NTf $\left.f_{2}\right]$ performing better than [Choline][ $\left.\mathrm{NTf}_{2}\right]$. In addition, EDS and XPS analysis demonstrated the temperature-related chemical interactions and their influence on tribological behaviour.
\end{abstract}

Keywords: ionic liquids, additives, lubrication, wind turbines gearbox, friction, wear.

\section{Introduction}

Wind energy is an important and strategic subject because of its relation with reduction of $\mathrm{CO}_{2}$ emissions and climate change; and wind turbines are broadly used in renewable electricity generation. The low rotating speed of the main shaft within a wind turbine requires the use of a turbine gearbox (multiple stages gear train) in order to multiply the speed of the secondary shaft until the correct angular velocity values used for the generator are reached [1]. The gearbox, more than any other component in a wind turbine, has the higher repair costs and greater downtimes because of failures. This fact has led to the manufacturing of direct drive wind turbines, but the comparison in terms of reliability between this new type and the geared drive still requires consideration. One of the most important problems of wind turbines is the fact that the optimum viscosity and anti-scuffing properties of oils are reached at temperatures above $80^{\circ} \mathrm{C}$. At temperatures lower than $60^{\circ} \mathrm{C}$, the anti-scuffing protection diminishes resulting in higher wear. On the other hand, above $80^{\circ} \mathrm{C}$ is difficult to maintain an effective lubricant film and that is why the utilization of synthetic oil in this situation is employed [2]. Friction between meshing teeth is the highest source of energy loss in the gearbox. However, the rolling bearing friction represents 
approximately $30 \%$ of the energy losses. These energy losses also depend on the physical and film forming properties of the gear oil [3-6].

Taking into account the industry challenge of improving tribological behaviour of material pairs, the development of high performance gearbox oils with the inclusion of new additives is one of the most promising approaches. The addition of ionic liquids (ILs) into novel high performance lubricants has been proposed several times [7]. The ILs are salts, formed by organic or inorganic cations and anions, with a melting point lower than $100^{\circ} \mathrm{C}$. The special characteristics of ILs are their chemical and thermal stability, tunable properties, electrical conductivity, low vapour pressure and high thermal conductivity. These characteristics allow the usage of ILs within different tribosystems, in vacuum applications, in harsh conditions, etc. [8].

Ye et al. [9] published the first paper on the use of ILs in lubrication demonstrating the excellent tribological behavior shown by different imidazolium-based ILs for various material pairs in sliding motion. Material pairs such as steel/steel, steel/ $\mathrm{SiO}_{2}$, steel/aluminium, steel/copper, steel/Si(100), steel/sialon, steel/titanium, sialon/ $\mathrm{Si}_{3} \mathrm{~N}_{4}$ and steel-PVD coatings (TiN, DLC and $\mathrm{CrN}$ ) have been explored using pyridinium, imidazolium, phosphonium or ammonium as cation combined with anions such as hexafluorophosphate $\left(\mathrm{PF}_{6}\right)$, tetrafluoroborate $\left(\mathrm{BF}_{4}\right), \mathrm{CF}_{3} \mathrm{SO}_{3},\left(\mathrm{C}_{2} \mathrm{~F}_{5}\right)_{3} \mathrm{PF}_{3}$ (or FAP) and $\left(\mathrm{CF}_{3} \mathrm{SO}_{2}\right)_{2} \mathrm{~N}$ (or $\mathrm{NTf}_{2}$ ) [9-26]. The most common anions examined in the tribology literature are $\mathrm{BF}_{4}$ and $\mathrm{PF}_{6}$, but their hydrolytic instability and tendency to produce corrosive HF have been reported [27]. Merck KGaA has developed a new category of ILs using the FAP anion, which has an improved hydrolytic stability [28]. Different FAP-anion based ILs have been studied both as additive and as a neat lubricant for different materials pairs exhibiting excellent friction and wear reducer behaviour [20-26]. Some review papers [2932] have detailed the advantages of using ILs in tribology, their thermal and oxidative stability, and their tribochemical reactions.

Two approaches have been explored concerning the use of ILs in lubrication: as pure lubricants or base stocks, but this solution has the problem of the higher cost of the ILs compared with hydrocarbon oils, and as lubricant additives, which is a cheaper solution even though the low solubility of ILs in non-polar hydrocarbon oils [33]. The friction and wear behaviour of ILs as additive or as pure lubricant have been studied using synthetic and mineral oils, or even fully formulated oils, as base oils or reference samples $[27,33-35]$ 
The additivation value of fully formulated oils with ILs needs further consideration and research. However, the combined effect of the IL with already existing oil additives has been studied by Qu et al. [36] demonstrating the improved performance of SAE 5W-30 engine oil with the addition of a phosphonium-based ionic liquid in a concentration of $5 \mathrm{wt} \%$. Similar result was obtained by Greco et al. [37] using $1 \mathrm{wt} \%$ of nano-colloidal boron nitride as an additive within a fully formulated wind turbine gearbox oil. Accordingly good antiwear properties, hydrolytic stability and hydrophobicity of the [ $\left.\mathrm{NTf}_{2}\right]$ anion reported by Minami et al. [16, 30]. This paper studies the effectiveness of using two ionic liquids (choline bis(trifluoromethylsulfonyl) imide, [Choline][ $\left.\mathrm{NTf}_{2}\right]$, and 1-butyl-1-methylpyrrolidinium bis(trifluoromethylsulfonyl)imide, $[\mathrm{BMP}]\left[\mathrm{NTf}_{2}\right]$ ) as an additivation to polyalphaolefin-based and mineral-based fully formulated lubricant for wind turbine gear oil applications.

\section{Experimental details}

Two fully formulated ISO VG 320 gear oils were employed in this study. A polyalphaolefin-based (FLENDER) and a mineral-based (FLENI) oils provided by Repsol, S.A. were considered as reference samples in this work. These products are used as lubricant for wind turbine gearbox applications. Their kinematic viscosity, viscosity index and density were measured using a SVM 3000 Stabinger viscometer and presented in Table 1. The chemical composition of these oils was previously determined by Fernandes et al. [2-4].

Table 1. Physical and chemical properties of reference lubricants.

\begin{tabular}{llll}
\hline Parameter & Unit & FLENDER & FLENI \\
\hline Base oil & $(-)$ & Polyalphaolefin & Mineral \\
& & & \\
Chemical composition & $(\mathrm{ppm})$ & 3.5 & 0.9 \\
$\quad$ Zinc (Zn) & $(\mathrm{ppm})$ & 0.5 & 0.9 \\
Magnesium (Mg) & $(\mathrm{ppm})$ & 415.9 & 354.3 \\
Phosphorus (P) & $(\mathrm{ppm})$ & 0.5 & 2.5 \\
Calcium (Ca) & $(\mathrm{ppm})$ & 28.4 & 22.3 \\
Boron (B) & $(\mathrm{ppm})$ & 5020 & 11200 \\
Sulfur (S) & & & \\
Physical properties & $\left(\mathrm{g} / \mathrm{cm}^{3}\right)$ & 0.860 & 0.90 \\
Density, $15^{\circ} \mathrm{C}$ & $(\mathrm{cSt})$ & 323.38 & 305.9 \\
Viscosity, $40^{\circ} \mathrm{C}$ & $(\mathrm{cSt})$ & 35.20 & 23.4 \\
Viscosity, $100^{\circ} \mathrm{C}$ & $\left(\mathrm{Pa}{ }^{-1}\right)$ & 1.590 & 2.207 \\
Piezoviscosity, $40^{\circ} \mathrm{C}\left(\alpha \cdot 10^{-8}\right)$ & $\left(\mathrm{Pa}^{-1}\right)$ & 1.182 & 1.527 \\
Piezoviscosity, $100^{\circ} \mathrm{C}\left(\alpha \cdot 10^{-8}\right)$ & $(-)$ & 154 & 96 \\
VI & & &
\end{tabular}


Both the choline bis(trifluoromethylsulfonyl) imide and 1-butyl-1-methylpyrrolidinium

bis(trifluoromethylsulfonyl)imide ionic liquids, provided by Ionic Liquid Technologies GmbH (Io-LiTec), were used as an additive in this work. The molecular structure and significant properties of these ionic liquids are shown in Table 2.

Table 2. Ionic liquid properties.

\begin{tabular}{|c|c|c|c|c|c|c|c|}
\hline \multicolumn{2}{|c|}{ Ionic Liquid } & \multirow{3}{*}{ IUPAC name } & \multirow{3}{*}{$\begin{array}{l}\text { Purity } \\
(\%)\end{array}$} & \multirow{3}{*}{$\begin{array}{c}\begin{array}{c}\text { Density } \\
\left(\mathrm{g} / \mathrm{cm}^{3}\right)^{*}\end{array} \\
15^{\circ} \mathrm{C}\end{array}$} & \multirow{2}{*}{\multicolumn{2}{|c|}{$\begin{array}{l}\text { Viscosity } \\
\left(\mathrm{mm}^{2} / \mathbf{s}\right)^{*}\end{array}$}} & \multirow{3}{*}{$\begin{array}{l}\text { Viscosity } \\
\text { Index* }\end{array}$} \\
\hline \multirow[t]{2}{*}{ Cation } & \multirow[t]{2}{*}{ Anion } & & & & & & \\
\hline & & & & & $40^{\circ} \mathrm{C}$ & $100^{\circ} \mathrm{C}$ & \\
\hline [Choline] & {$\left[\mathrm{NTf}_{2}\right]$} & $\begin{array}{l}\text { Choline } \\
\text { bis(trifluoromethylsulfonyl)imide }\end{array}$ & $>99$ & 1.53 & 40.429 & 7.744 & 165 \\
\hline [BMP] & {$\left[\mathrm{NTf}_{2}\right]$} & $\begin{array}{l}\text { 1-Butyl-1-methylpyrrolidinium } \\
\text { bis(trifluoromethylsulfonyl)imide }\end{array}$ & $>99$ & 1.40 & 28.826 & 6.228 & 174 \\
\hline
\end{tabular}

* Measured in a SVM 3000 Stabinger viscometer (ASTM D7042, D2270)

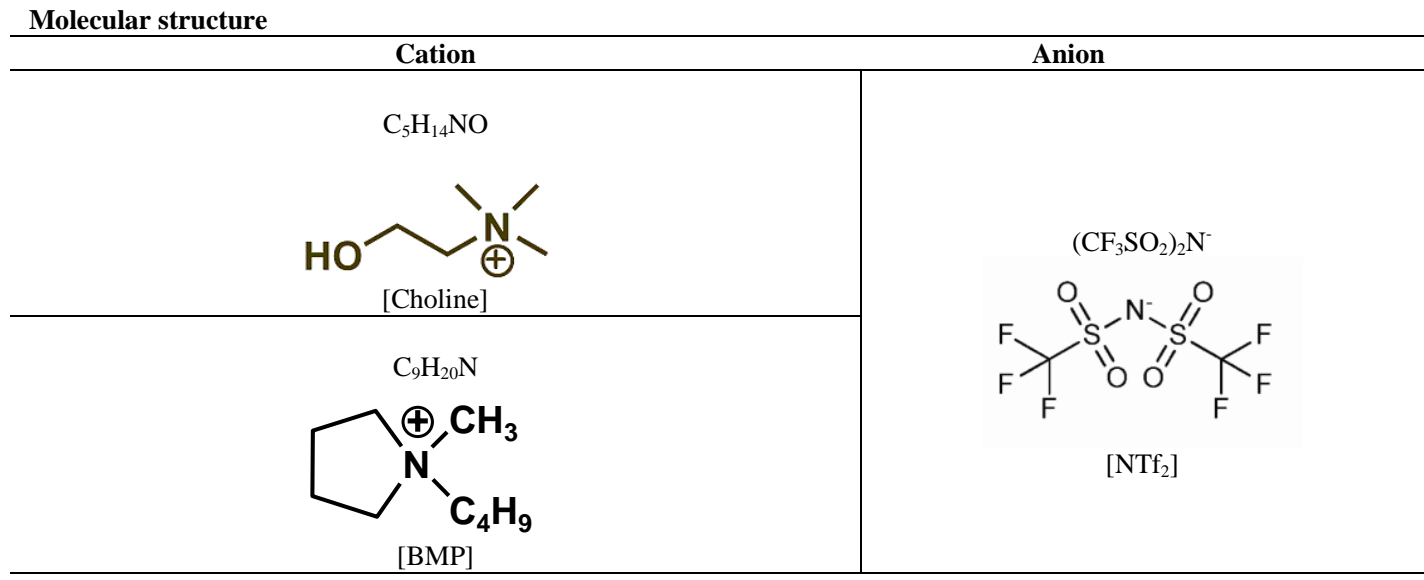

Before the tribological tests both ionic liquids at $5 \mathrm{wt} \%$ were separately mixed with FLENDER and FLENI, respectively, using an ultrasonic probe (Bandelin Sonoplus HD2200) at 70\% of amplitude for 5 minutes and controlling the temperature of the samples below $60^{\circ} \mathrm{C}$. A Turbiscan Lab was also used to study during 96 hours the stability of the suspensions by light backscattering. The results showed that all suspensions remained stable for this period, only a slight increase of approximately 5\% in light transmission was found at the top of the sample at the end of test. This fact is related to sedimentation, phenomenon that is characteristic of mixtures where the dispersed phase (the ionic liquid in this case) has a higher density than the continuous phase (gear oil). Therefore the stability of all samples was always higher than the planned tribological testing time. The SVM 3000 Stabinger viscometer was also used to measure the viscosity of the suspensions, Table 3 . The viscosity results showed that the maximum increase of the mixture viscosity with regard to FLENDER was between $3.4-6 \%$ at $40^{\circ} \mathrm{C}$ and $2.9-10.2 \%$ at $100^{\circ} \mathrm{C}$, and between $3.8-4.6 \%$ at $40^{\circ} \mathrm{C}$ and $5-6.5 \%$ at $100^{\circ} \mathrm{C}$ with regard to FLENI. 
Thermogravimetric analysis (TGA) was used to determine the decomposition temperature of the pure lubricants and their blends with the two ionic liquids. Tests were carried out on a Mettler Toledo TGA/SDTA $851^{\mathrm{e}}$ from ambient temperatures to approximately $600^{\circ} \mathrm{C}$ at a $2.5^{\circ} \mathrm{C} / \mathrm{min}$ heating rate in oxygen atmosphere. Although the well-known high thermal stability $\left(>300^{\circ} \mathrm{C}\right)$ of the ionic liquids, the addition of 5\%wt. of both ionic liquids to the polyalphaolefin-based and mineral-based gear oils did not improve the thermal stability of the blends, which showed a decomposition temperature around $230^{\circ} \mathrm{C}$ (similar to the values of the gear oils). These results are similar to the ones obtained by Yu et al. [38].

Table 3. Properties of the gear oils and its mixtures with $5 \mathrm{wt} \%$ of the ionic liquids.

\begin{tabular}{|c|c|c|c|c|}
\hline \multirow{2}{*}{ Gear Oils + Ionic liquids } & \multirow{2}{*}{$\frac{\text { Density }\left(\mathrm{g} / \mathrm{cm}^{3}\right)^{*}}{15^{\circ} \mathrm{C}}$} & \multicolumn{2}{|c|}{ Viscosity, $\mathrm{mm}^{2} / \mathrm{s}(\mathbf{m P a} \cdot \mathbf{s})^{*}$} & \multirow[t]{2}{*}{ Viscosity Index* } \\
\hline & & $40^{\circ} \mathrm{C}$ & $100^{\circ} \mathrm{C}$ & \\
\hline FLENI & 0.900 & $305.90(270.67)$ & $23.40(19.878)$ & 96 \\
\hline$+5 \%[\mathrm{BMP}]\left[\mathrm{NTf}_{2}\right]$ & 0.912 & $317.59(291.28)$ & $24.58(21.223)$ & 99 \\
\hline$+5 \%[$ Choline $]\left[\mathrm{NTf}_{2}\right]$ & 0.915 & $320.06(288.05)$ & $24.92(21.529)$ & 100 \\
\hline FLENDER & 0.860 & $323.38(273.42)$ & $35.20(28.50)$ & 154 \\
\hline$+5 \%[\mathrm{BMP}]\left[\mathrm{NTf}_{2}\right]$ & 0.870 & $334.50(290.17)$ & $36.22(30.68)$ & 155 \\
\hline$+5 \%[$ Choline $]\left[\mathrm{NTf}_{2}\right]$ & 0.915 & $342.68(293.75)$ & $38.79(31.68)$ & 164 \\
\hline
\end{tabular}

* Measured in a SVM 3000 Stabinger viscometer (ASTM D7042, 2270)

A Bruker UMT-3 reciprocating ball-on-plate microprocessor-controlled machine was used to perform the tribological (friction and wear) tests. The 60-minutes tests were conducted at temperature of $40^{\circ} \mathrm{C}$ for loads of 60 and $100 \mathrm{~N}$ (corresponding to a maximum contact pressure of 1.91 and $2.26 \mathrm{GPa}$, respectively) and at temperature of $100^{\circ} \mathrm{C}$ for a load of $60 \mathrm{~N}$, using in all cases a frequency of $20 \mathrm{~Hz}$ and stroke length of $2 \mathrm{~mm}$ in the presence of $4 \mathrm{~mL}$ of the corresponding lubricant sample. Tests were conducted in room air with a relative humidity in the range $20-30 \%$. The upper specimen used was AISI 52100 chrome steel balls $(0.98-1.1 \% \mathrm{C}, 0.15-0.30 \% \mathrm{Si}, 0.25-0.45 \% \mathrm{Mn}, 1.30-1.60 \% \mathrm{Cr},<0.025 \% \mathrm{P},<0.025 \% \mathrm{~S})$ with 9.5 mm diameter, hardness of $63 \mathrm{HRC}$ and approximately $0.1 \mu \mathrm{m}$ of surface finish (Ra). The lower specimen was AISI 52100 steel discs (machined from annealed rod) with a hardness of 190-210 $\mathrm{HV}_{30}$ and less than $0.02 \mu \mathrm{m}$ of surface finish (Ra). Both specimens were cleaned before tribological tests with heptane in an ultrasonic bath for 5 minutes, rinsed in ethanol and air dried. The lubricant samples were tested three times under each test condition.

Corrosion character of the blends was studied by simple corrosivity tests, applying separately all the lubricants studied on the steel discs surfaces (previously cleaned and dried) for three weeks at room temperature while the corrosion activity was observed. Also, and according with other authors [39], 
additional corrosion tests were made. The steel discs were dipped into the different lubricants and maintained at $100^{\circ} \mathrm{C}$ for $10 \mathrm{~h}$. After both tests surfaces were analysed by means of optical and scanning electron microscopy and by energy dispersive spectroscopy (EDS). However non corrosion activity was observed.

The specimens were also cleaned by rinsing in ethanol and air drying after tribological tests. The wear volume on the discs was measured using a Leica DCM 3D confocal microscope. X-Ray photoelectron spectroscopy (XPS) and scanning electron microscopy and energy dispersive spectroscopy (SEM-EDS) were also employed to analyse and evaluate the interaction of the lubricant with the worn surface. XPS measurements were performed under ultra-high vacuum conditions (ca. 9.10 ${ }^{-10}$ mbar) using $\mathrm{K} \alpha \mathrm{Mg}$ (energy $1253.6 \mathrm{eV}$ ) at $200 \mathrm{~W}$ and $11 \mathrm{kV}$. The energy analyser was set in a constant pass energy mode and the electromagnetic lenses in high magnification mode. Low resolution spectra were taken with pass energy of $90 \mathrm{eV}$ and step energy of $1 \mathrm{eV}$ whereas high resolution spectra were taken with pass energy of $30 \mathrm{eV}$ and step energy of $0.1 \mathrm{eV}$. Spatial resolution for analysing the wear scar was achieved by co-using the electromagnetic lenses of the analyser together with the detector slit, set as a $3 \mathrm{~mm}$ diameter circle. The position of $\mathrm{C} 1 \mathrm{~s}$ spurious carbon was used to detect whether charge correction was needed. High resolution spectra were taken for iron, fluorine, oxygen, phosphorus and sulphur taking into account the composition of the ionic liquid, the steel and previous experience of the authors [20-26].

Mathematical fitting of the spectra was carried out using Shirley-type baseline [40] and a Gaussian (70\%)-Lorentzian $(30 \%)$ product as model curve. The fitting procedure was performed with CasaXPS software using Levenberg-Marquardt algorithm, although supplementary optimization with the modified simplex algorithm was carried out with author's own software [41].

\section{Results and discussions}

\subsection{Friction and wear tests}

The mean value of friction coefficient of the fully formulated gear oils (FLENI and FLENDER) and their mixtures with $5 \mathrm{wt} \%$ of the two ionic liquids under the test conditions is shown in Fig. 1. The friction coefficient values obtained are characteristics of the mixed and boundary lubrication regimes [19]. 

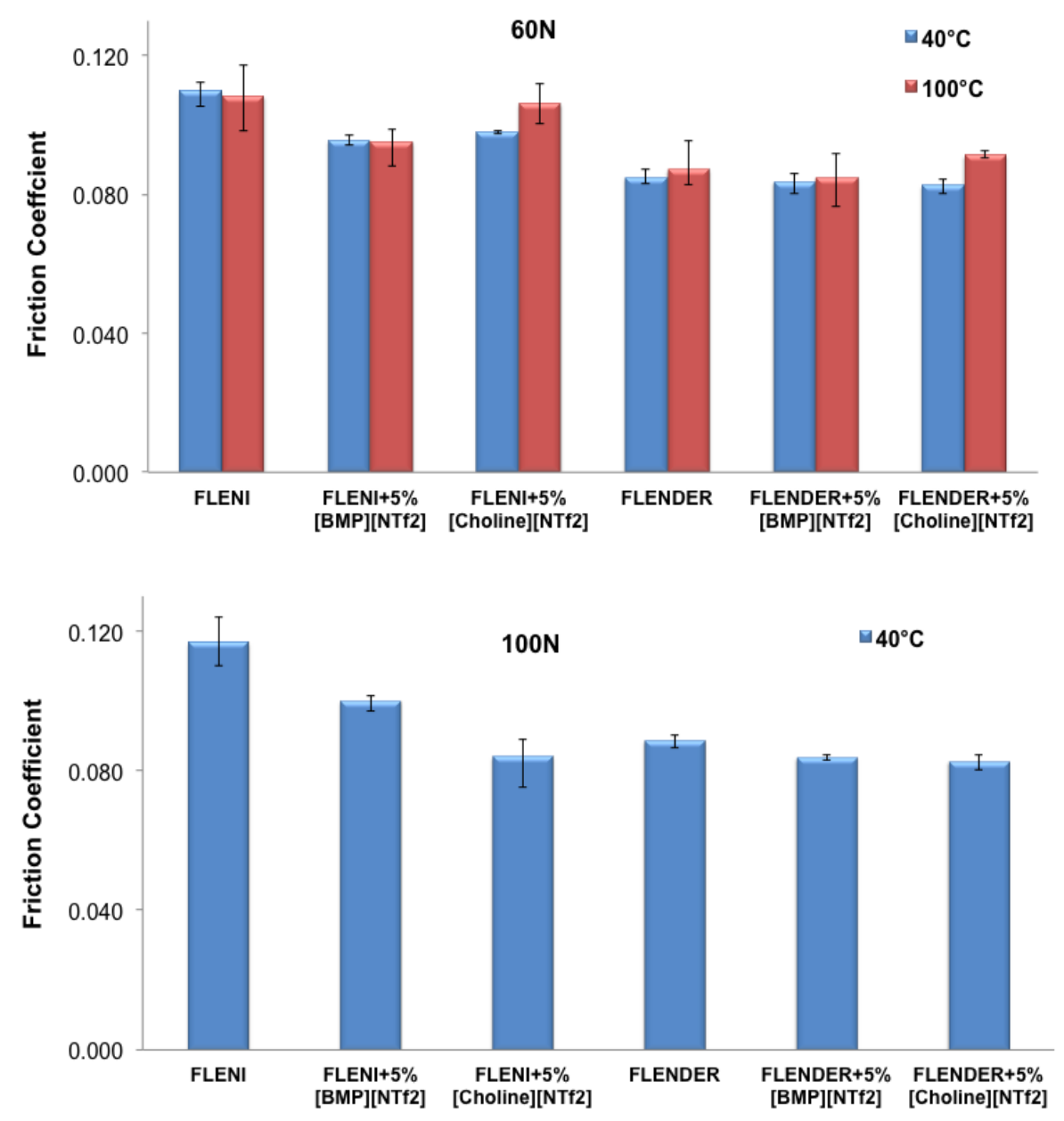

Fig. 1. Friction behaviour of the fully formulated gear oils and its mixtures with the ionic liquids.

For FLENI gear oil and its mixture with [BMP][NTf 2 , the friction coefficient under the load of $60 \mathrm{~N}$ was quite similar at 40 and $100^{\circ} \mathrm{C}$, with lower values than the FLENI ones. This friction reduction behaviour of the ionic liquid in low polarity oils such as mineral oils is closely related to its polar character which facilitates the migration of the ILs to metal surfaces and formation of physical bonds with the oxide layer on the surface [42-44] and their synergistic action with the additives included in the formulation of the gear oil. For the mixtures with $[$ Choline $]\left[\mathrm{NTf}_{2}\right]$, friction coefficient increased its value when temperature changed from 40 to $100^{\circ} \mathrm{C}$. At $40^{\circ} \mathrm{C}$ [Choline] $\left[\mathrm{NTf}_{2}\right]$ mixture has a lower friction coefficient than the pure FLENI lubricant, showing once again the friction reduction character of the ionic liquid. Interestingly, at $100^{\circ} \mathrm{C}$ [Choline] $\left[\mathrm{NTf}_{2}\right]$ mixture has similar friction results to FLENI probably due to the decrease of viscosity values approaching the FLENI lubricant, Table 3. The friction coefficient under $100 \mathrm{~N}$ and $40^{\circ} \mathrm{C}$-tests showed a higher friction value for FLENI with regard to the $60 \mathrm{~N}$-test, but all the mixtures showed significantly lower friction coefficient than FLENI under these conditions. Some friction values at $100 \mathrm{~N}$ and $40^{\circ} \mathrm{C}$ were lower or higher than its counterparts at $60 \mathrm{~N}$ and $40^{\circ} \mathrm{C}$ not only due to the 
reaction of active element present in FLENI oil and also in the ILs, Tables 1 and 2, but also due to the two competing processes of tribofilm formation and removal (wear) [34].

The friction coefficient obtained with FLENDER and its mixtures at $60 \mathrm{~N}$ for both temperatures was quite similar, the increase of $4.6 \%$ for the sample with [Choline][ $\left.\mathrm{NTf}_{2}\right]$ at $100^{\circ} \mathrm{C}$ in comparison with FLENDER is between the range of measured values deviation. The results obtained under the $100 \mathrm{~N}$-load at $40{ }^{\circ} \mathrm{C}$ were similar for FLENDER and its mixtures with the ionic liquids. Interestingly, when the load increases from 60 to $100 \mathrm{~N}$ at $40^{\circ} \mathrm{C}$, a slight increase in friction coefficient was found in FLENDER samples, but the mixtures has an identical friction response.

The mean values of friction coefficient were taken from the measurements of friction versus time recorded during the tribological tests. Figure 2, as an example, shows the friction coefficient versus time for the samples lubricated with FLENI and its blends with the two ionic liquids under all the test conditions. It can be observed nearly constant values of friction coefficient, especially for the tests made at $40^{\circ} \mathrm{C}$ (for both loads), while at $100^{\circ} \mathrm{C}$ the instantaneous friction values are slightly unstable. The friction behaviour in the case of FLENDER and its mixtures were similar to the FLENI counterparts.
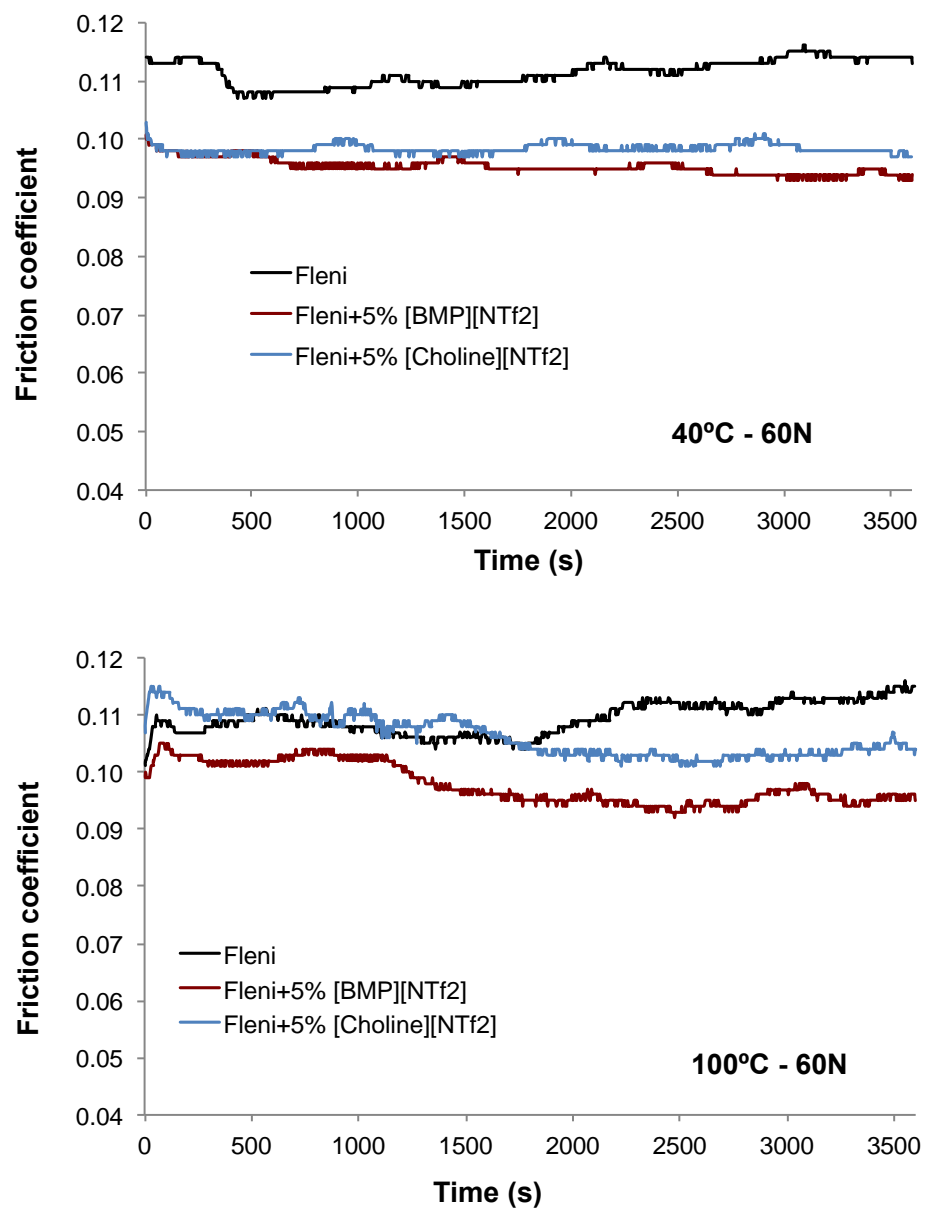


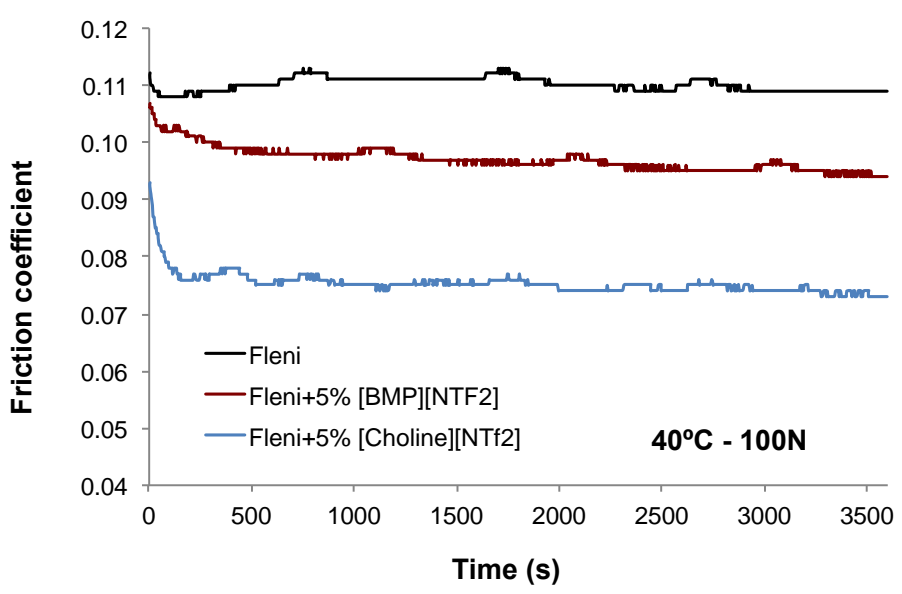

Fig. 2. Friction coefficient as a function of time of the samples lubricated with FLENI and its mixtures with the ionic liquids under the three test conditions.

In terms of wear measured on the disc surfaces (Fig. 3), it can be found that the rise in temperature at 60 $\mathrm{N}$-load provoked the increase of wear volume for all lubricant samples, although all the mixtures with ionic liquids showed lower wear results than the pure gear oils ones (FLENDER and FLENI, respectively). The same behaviour can be observed in the results obtained under the load of $100 \mathrm{~N}$. Under both loads and temperatures the mixtures with $5 \mathrm{wt} \%$ of $[\mathrm{BMP}]\left[\mathrm{NTf}_{2}\right]$ presented an increased performance. In particular, the FLENI tests made at $100 \mathrm{~N}-\mathrm{load}$ and $40^{\circ} \mathrm{C}$ with $5 \mathrm{wt} \%$ of [Choline][ $\left.\mathrm{NTf}_{2}\right]$ exhibited the lowest wear, corresponding with associated friction results (Fig. 1). Wear results of the counterbody (AISI 52100 chrome steel balls) are not reported because wear scar was practically undetectable in most cases, with only a slight roughness variation on the samples tested at $100^{\circ} \mathrm{C}$.

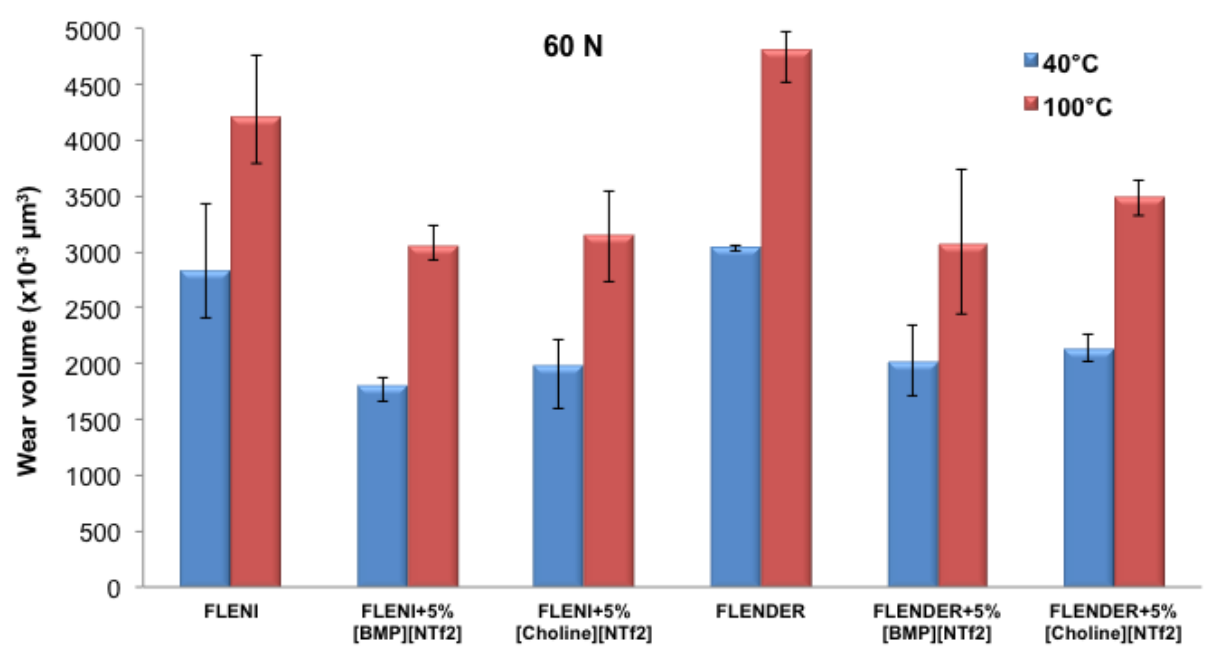




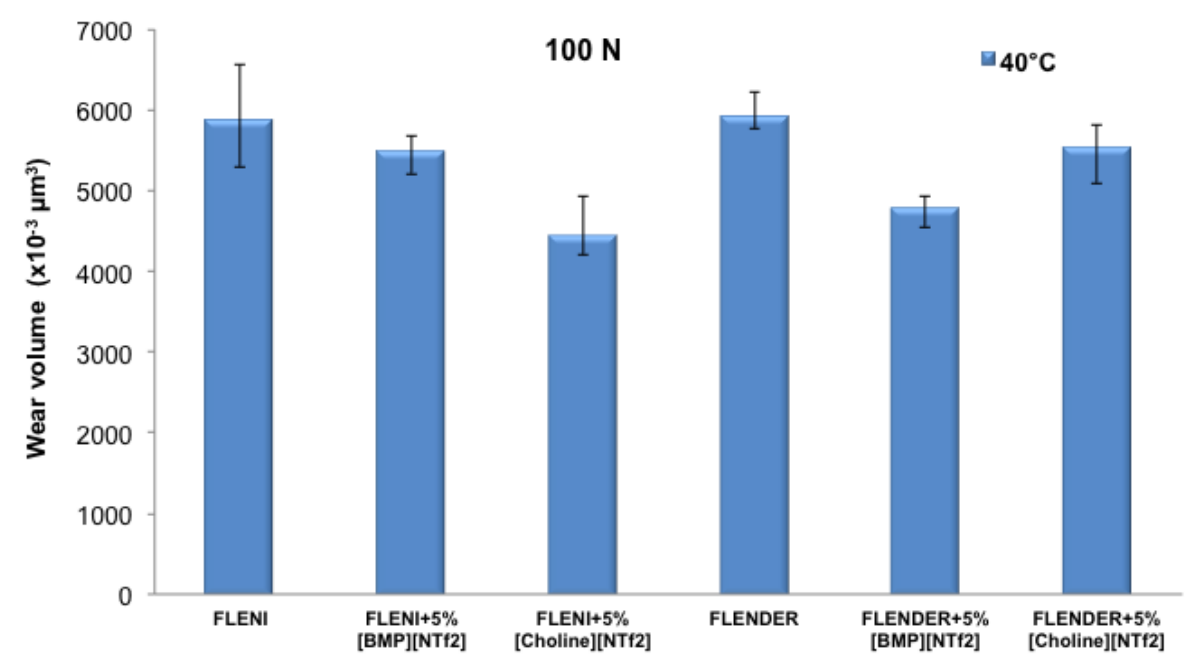

Fig. 3. Wear behaviour of the fully formulated gear oils and its mixtures with the ionic liquids.

\subsection{Surface analysis}

Fig. 4 shows the images of the wear surfaces, lubricated with FLENDER and its mixtures with the two ionic liquids, taken from the SEM analysis. It can be observed how the increase of severity in test conditions (increase of load or temperature) led to a higher wear result (larger wear scar). Also, it can be seen at the highest magnification that the addition of the ionic liquid in the gear oil reduced wear severity. Similar behaviour was observed in the worn surfaces after the tests with FLENI and its mixtures with both ionic liquids.

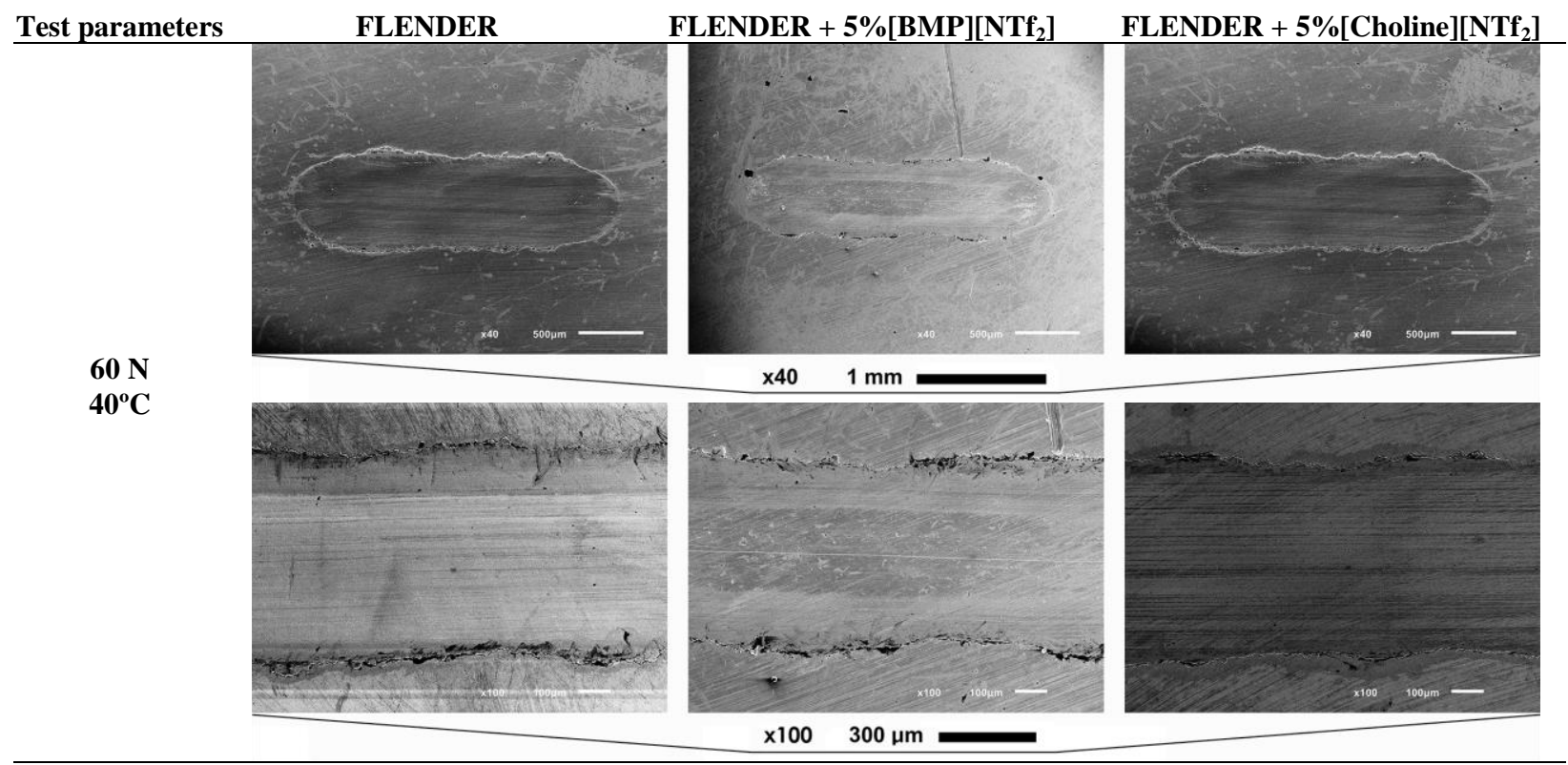


$60 \mathrm{~N}$

$100^{\circ} \mathrm{C}$
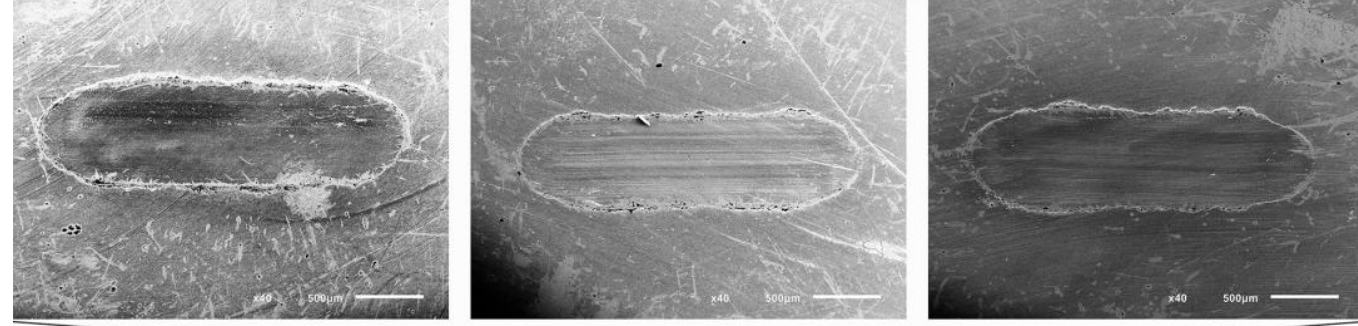

$\mathbf{x} 40 \quad 1 \mathrm{~mm}$
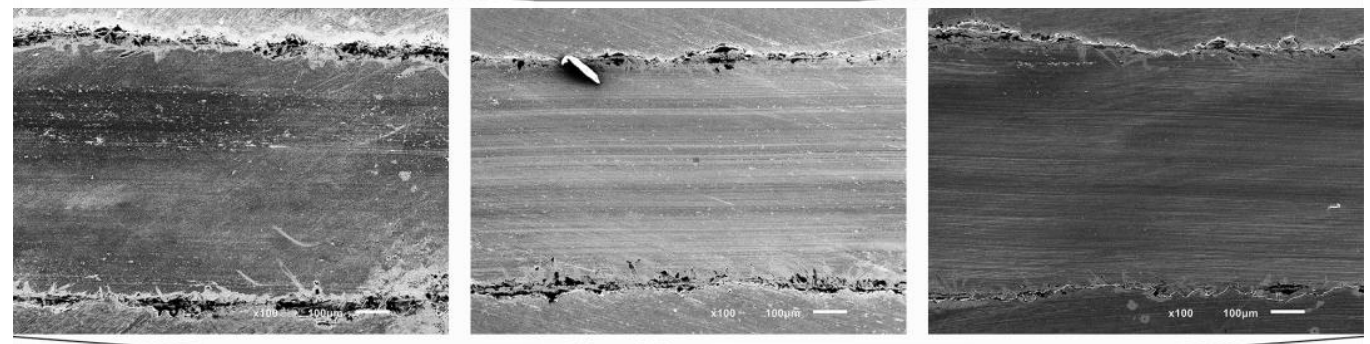

$\mathrm{x} 100 \quad 300 \mu \mathrm{m}$
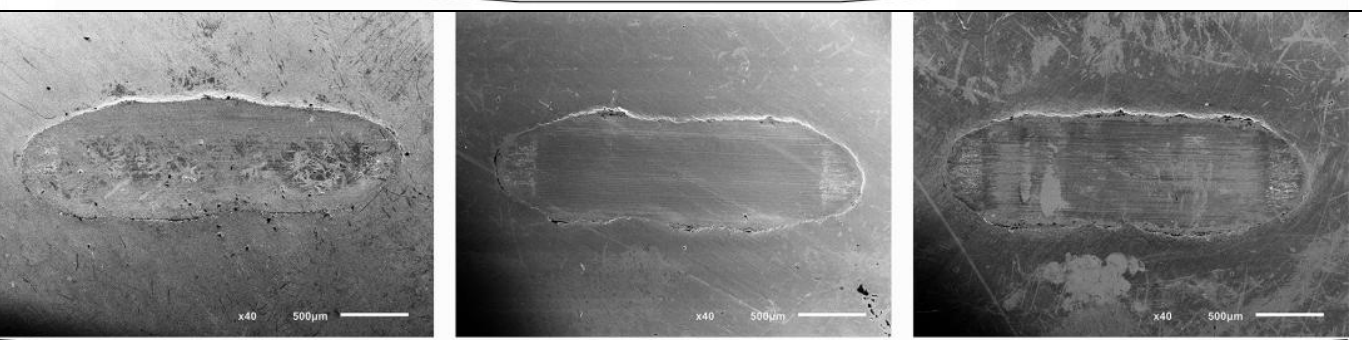

$100 \mathrm{~N}$

$40^{\circ} \mathrm{C}$

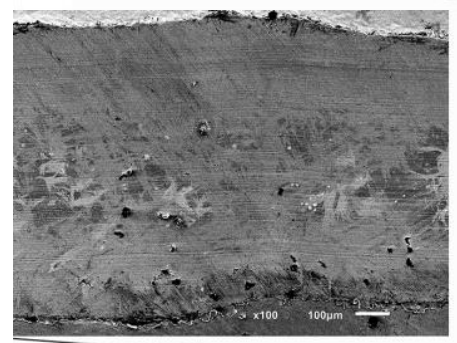

$\times 40$
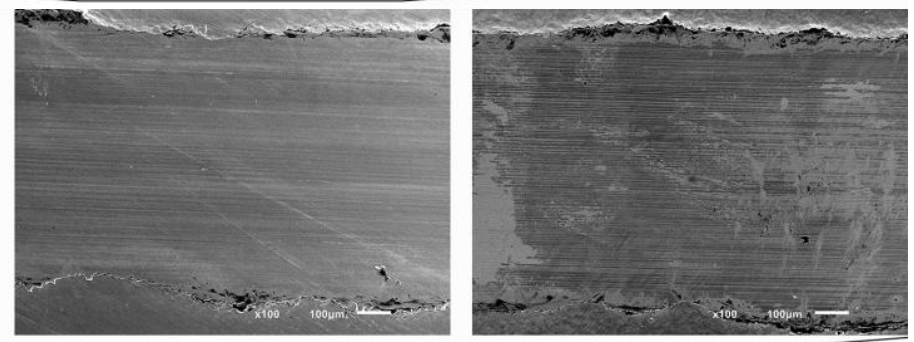

$\mathrm{x} 100 \quad 300 \mu \mathrm{m}$

Fig. 4. SEM micrographs of wear surfaces lubricated with FLENDER mixtures under all test conditions (upper row: 40x of magnification and $500 \mu \mathrm{m}$ of scale bar length / lower row: 100x of magnification and $100 \mu \mathrm{m}$ of scale bar length).

Fig. 5 shows an elemental EDS analysis positioned on the central part of the worn surface lubricated with the mixtures with $5 \mathrm{wt} \%$ of [BMP][NTf 2 for both gears oils under the three test conditions of load and temperature. The EDS analysis shows that at $40^{\circ} \mathrm{C}$ for both loads the elements found on the worn surface are the elements present in the steel composition, which verify that the active components of the gear oils (phosphorus, P, and sulphur, S) did not react with the surface. So the improvement in wear behaviour under that temperature condition $\left(40^{\circ} \mathrm{C}\right)$ is more likely related to the adsorption of ionic liquid on the surface. Although the ionic liquids also have active components, the EDS technique is not very suitable for analysis of thin tribofilms. 
On the other hand, in the $100^{\circ} \mathrm{C}$-tests the active components of the lubricant ( $\mathrm{P}$ and $\mathrm{S}$ ) reacted with the surface. The elemental analysis found sulphur on all the worn surfaces demonstrating the reaction of this element. This phenomenon was also verified for the FLENDER and FLENI samples without ionic liquids and for the mixtures with $5 \mathrm{wt} \%$ of $[$ Choline $]\left[\mathrm{NTf}_{2}\right]$, therefore sulphur originates from the additive package present in the formulation of the gear oils. Although, the improved wear results of the mixtures with regard to the gear oils used as reference (FLENI and FLENDER) can be related to combined effect of the original additive package and the presence of the ionic liquid. In addition, the EDS analysis made for the surfaces lubricated with FLENI with $5 \mathrm{wt} \%$ of $[\mathrm{BMP}]\left[\mathrm{NTf}_{2}\right]$, shows also the activation of P, probably related to the lower viscosity values of FLENI (Table 3) which led to a greater interaction between surfaces.

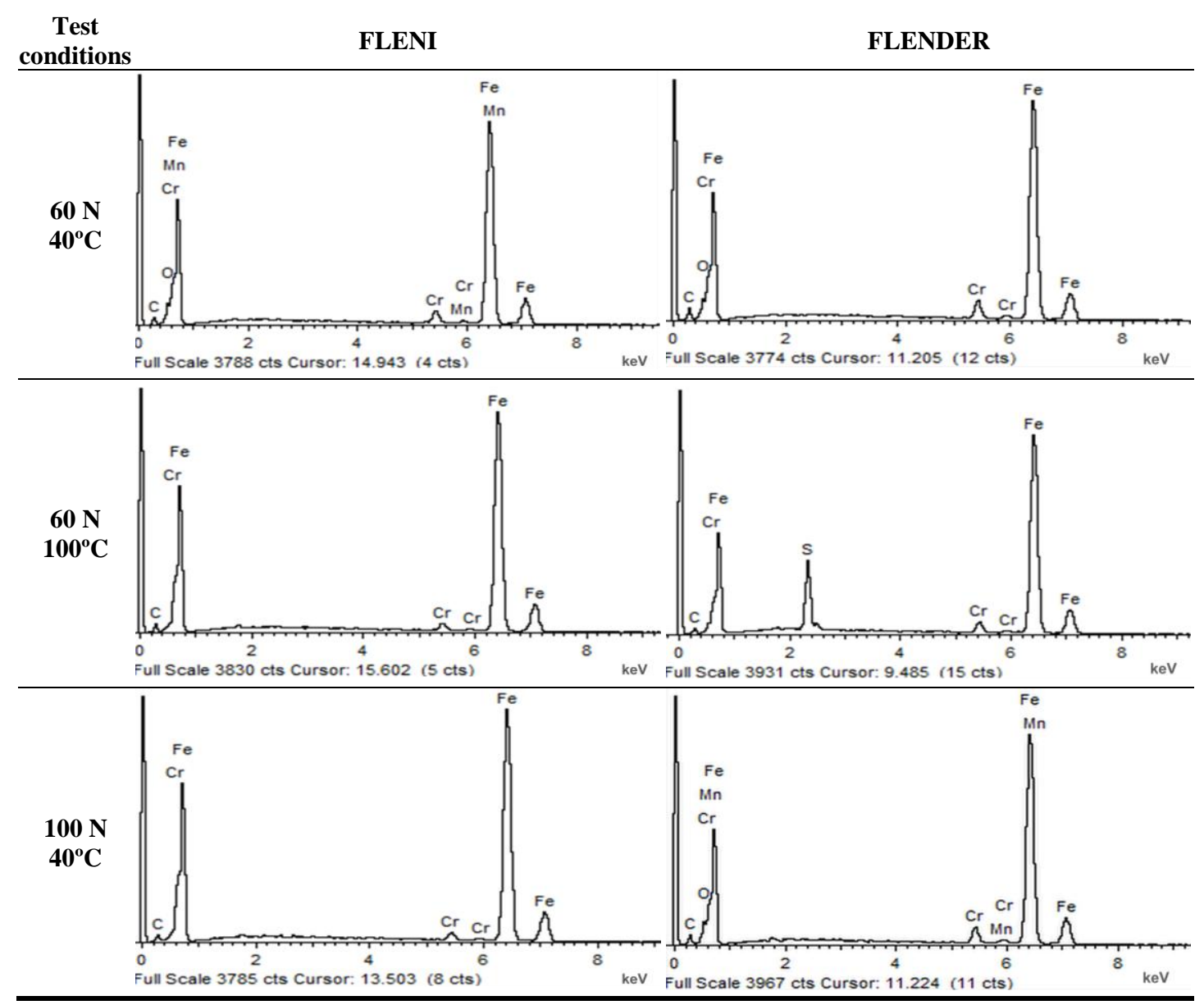


Test
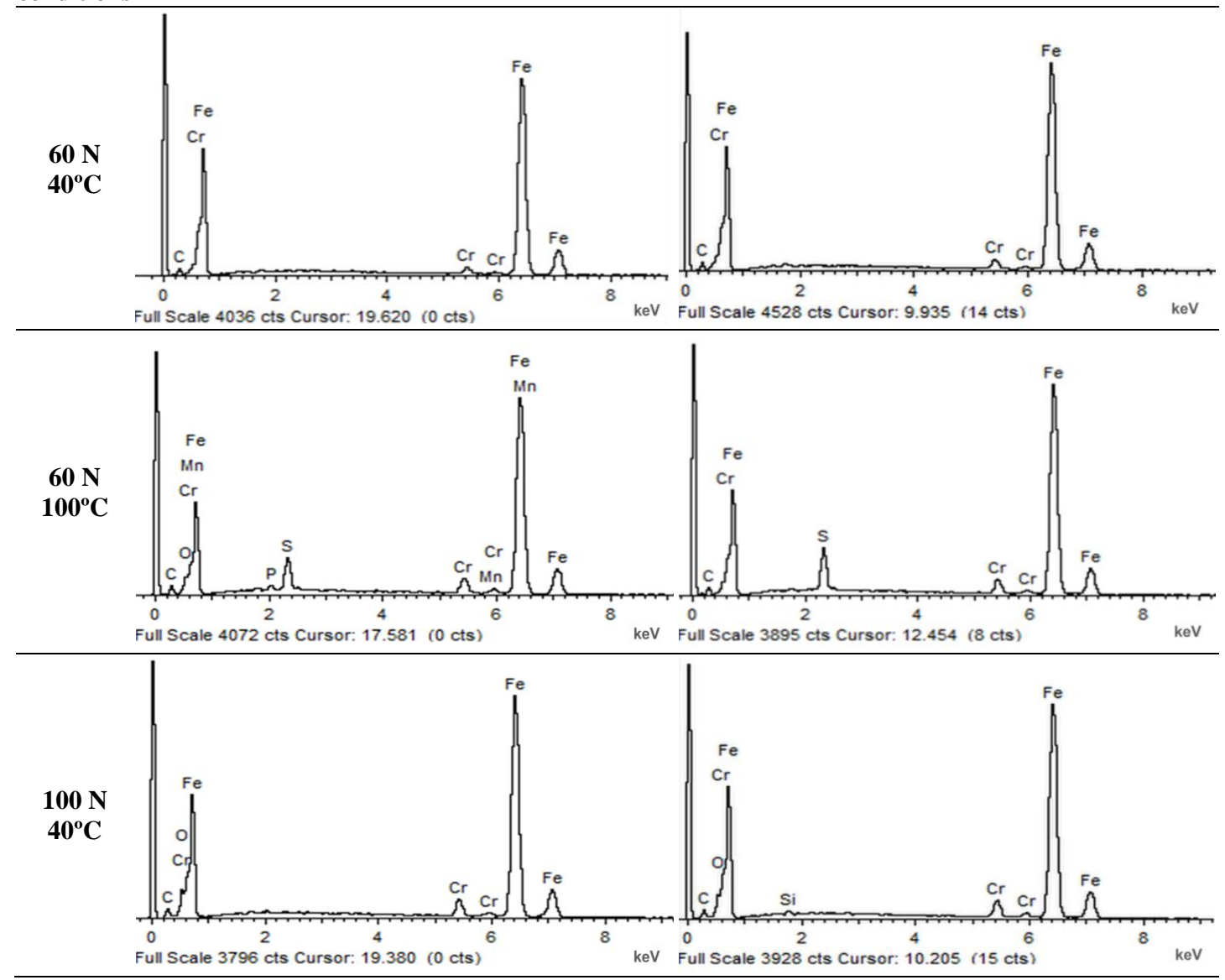

Fig. 5. EDS analysis of the central part of the wear surfaces under all test conditions.

The XPS experiments corroborate the issues observed by EDS but show a more complete analysis due to the possibility to analyse thinner tribofilms. Sulphur and phosphorus could not be detected in samples lubricated at low temperature $\left(40^{\circ} \mathrm{C}\right)$ whereas $\mathrm{P}$ presence becomes evident in those samples at $100^{\circ} \mathrm{C}$, both with $[\mathrm{BMP}]\left[\mathrm{NTf}_{2}\right]$ or $[$ Choline $]\left[\mathrm{NTf}_{2}\right]$, either in FLENDER or in FLENI. A high resolution analysis of P in the P2p band allows identifying iron phosphate in every sample, as summarized in Table 4 and according to the experiments of Otero et al. [45], who assigns $\mathrm{P} 2 \mathrm{p}$ band for $\mathrm{FePO}_{4}$ at $133.7 \mathrm{eV}$. These results seem to suggest that a P-containing additive of the gear oils (FLENDER and FLENI) which becomes active at high temperature is interacting with the surface to generate $\mathrm{FePO}_{4}$.

Table 4. Summary of the position of the P $2 p$ band for the different samples lubricated at $100^{\circ} \mathrm{C}$.

\begin{tabular}{lccc} 
& {$\left[\mathbf{B M P}_{[}\left[\mathbf{N T f}_{\mathbf{2}}\right]\right.$} & {$\left[{\text { Choline }]\left[\mathbf{N T f}_{\mathbf{2}}\right]}_{1}\right.$ Neat } \\
\hline FLENDER & $133.3 \mathrm{eV}$ & $133.5 \mathrm{eV}$ & $133.6 \mathrm{eV}$ \\
FLENI & $133.5 \mathrm{eV}$ & $133.5 \mathrm{eV}$ & $133.4 \mathrm{eV}$ \\
\hline
\end{tabular}


High resolution analysis of Fe2p3/2 (Figures 6 and 7) reveals a mixture of iron oxides and iron hydroxyoxides. Although the chemical differentiation among certain types of iron oxides using the Fe2p3/2 region is problematic [46], it is clear that the surfaces are composed mainly of $\mathrm{Fe}_{2} \mathrm{O}_{3}$ (described at $710.8 \mathrm{eV}$ [47] or also $710.4 \mathrm{eV}$ according to Nefedov and Salyn [48]) and FeOOH (aprox. $711.3 \mathrm{eV}$ or even $711.8 \mathrm{eV}$ $[47,49,50])$, although $\mathrm{FePO}_{4}$ can also be found in those samples (described at $712.8 \mathrm{eV}$ [51]) lubricated at high temperature, as previously seen in the P2p band.
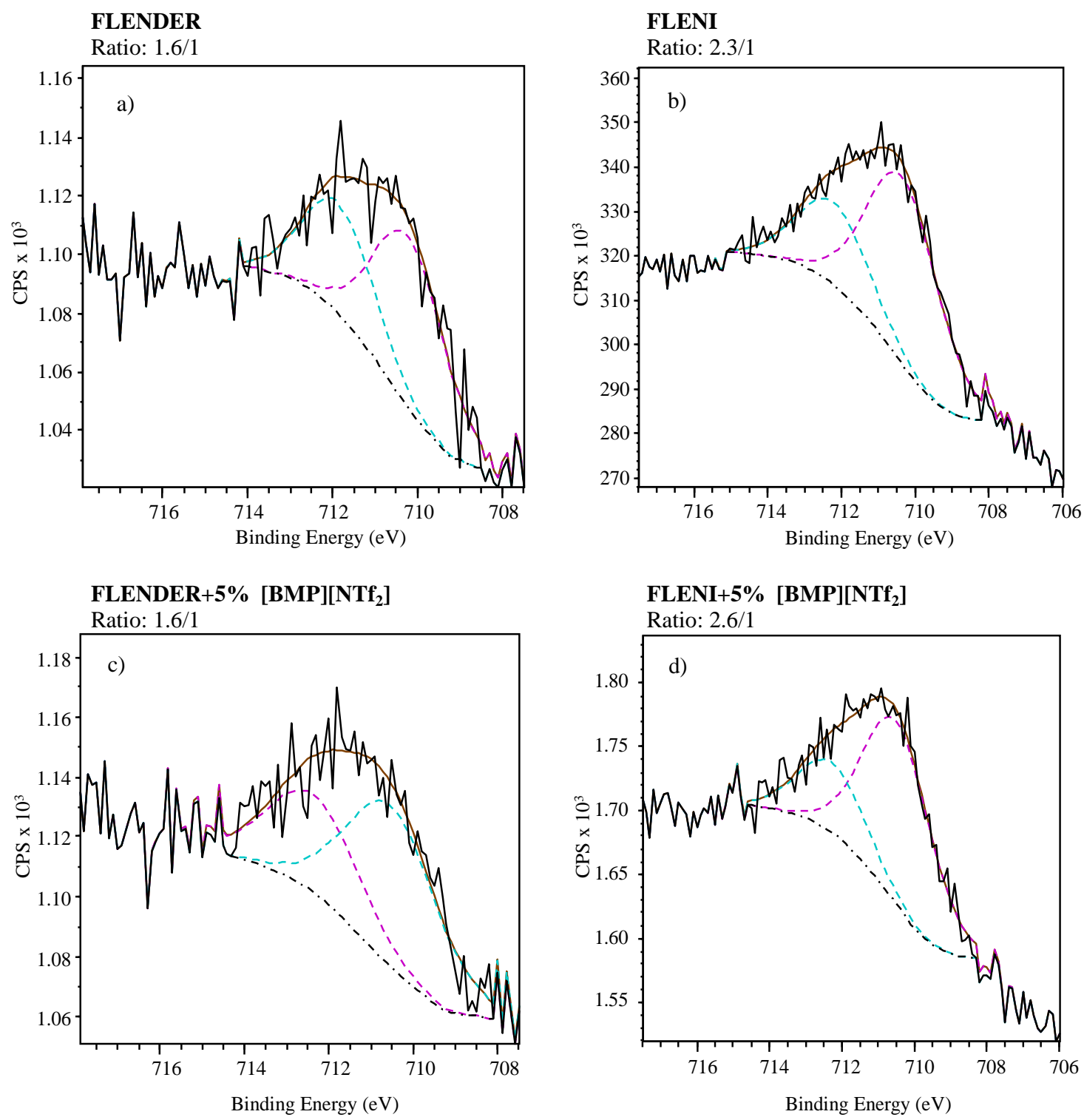
FLENDER+5\% [Choline][NTf ] $_{2}$ Ratio is $\mathrm{Fe}_{2} \mathrm{O}_{3} / \mathrm{FeOOH}$ areas ratio.
FLENI+5\% [Choline][NTf f $_{2}$

Ratio: $2 / 1$

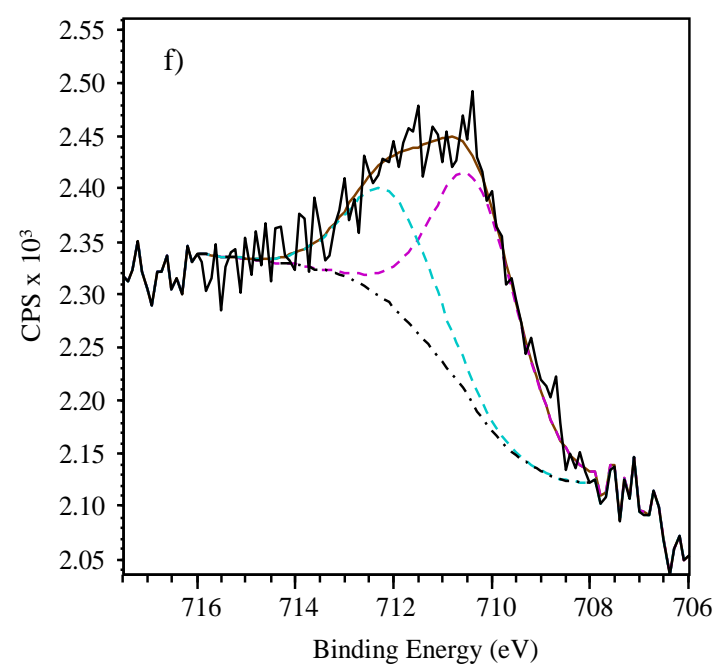

Fig. 6. Spectra with deconvoluted peaks of the $\mathrm{Fe} 2 \mathrm{p} 3 / 2$ band for the different samples lubricated at $40^{\circ} \mathrm{C}$.
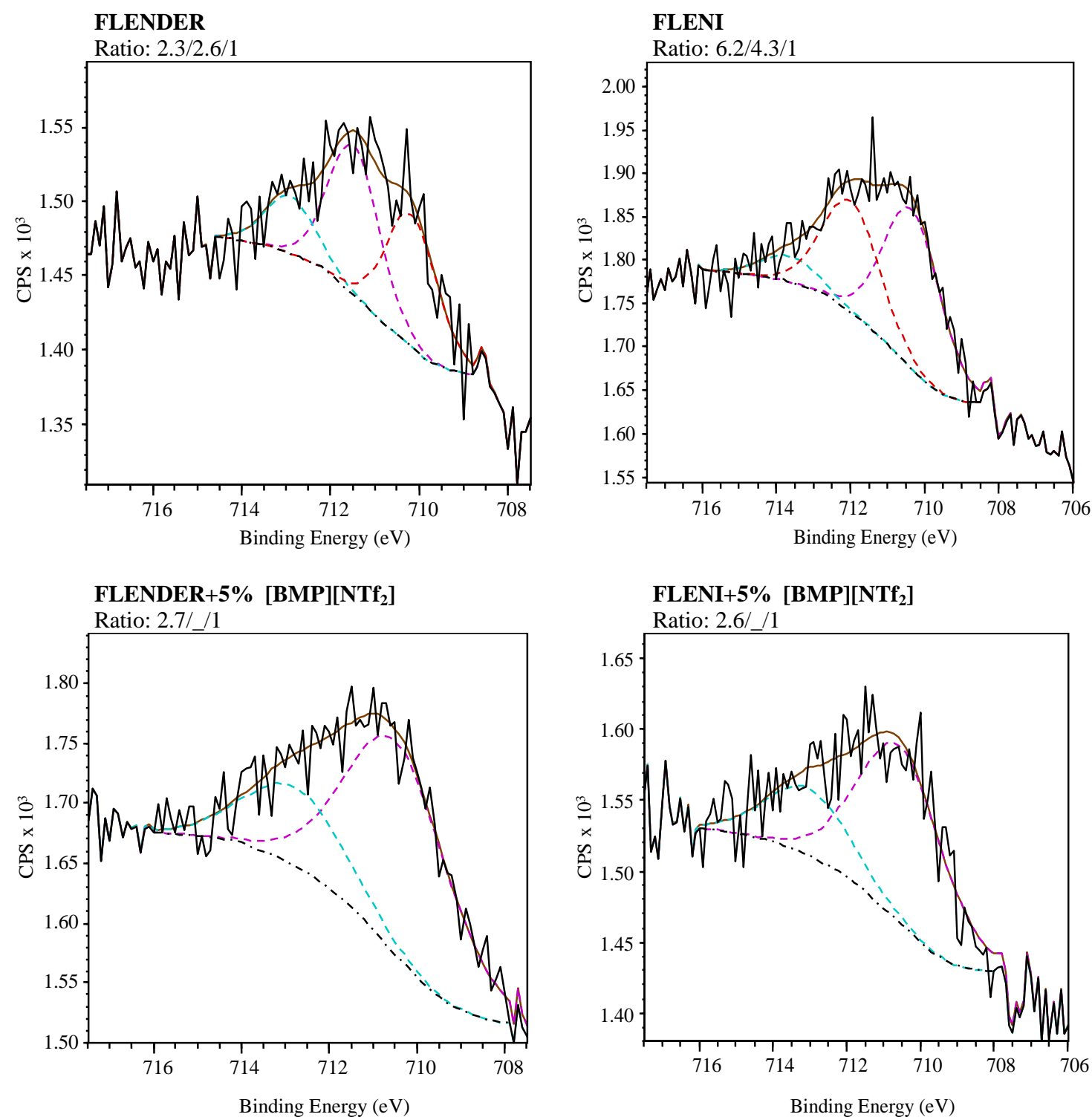

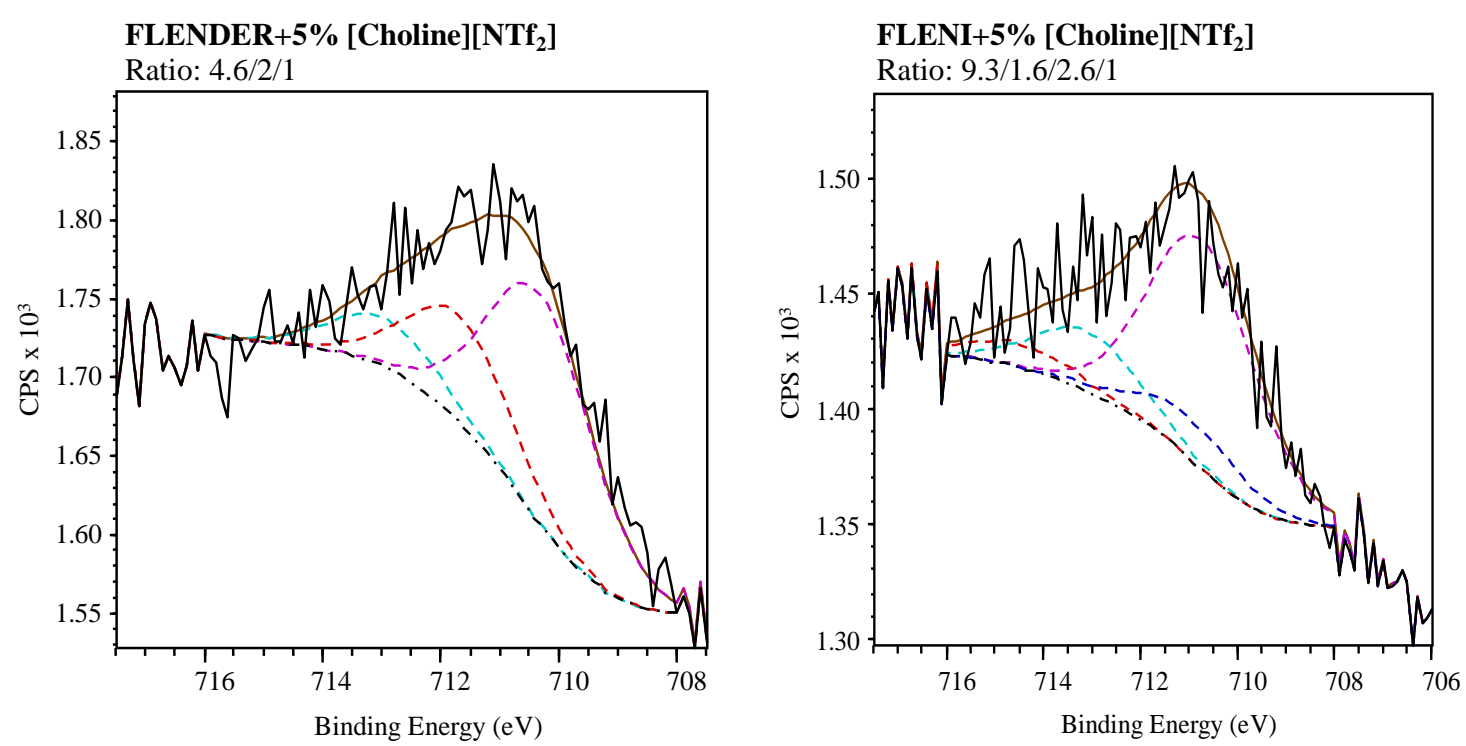

Fig. 7. Spectra with deconvoluted peaks of the $\mathrm{Fe} 2 \mathrm{p} 3 / 2$ band for the different samples lubricated at $100^{\circ} \mathrm{C}$. Ratio is $\mathrm{Fe}_{2} \mathrm{O}_{3} / \mathrm{FeOOH} / \mathrm{FePO}_{4}$ areas ratio.

From the above results, it can be concluded that at $40^{\circ} \mathrm{C}$ (Fig. 6) the $\mathrm{Fe}_{2} \mathrm{O}_{3} / \mathrm{FeOOH}$ ratio on the surface does not depend on the ionic liquid used but on the gear oil. In fact, this ratio keeps more or less constant even if no ionic liquid is added to the gear oil. The amount of iron hydroxy-oxide is lower with FLENI than with FLENDER, probably due to its chemical properties.

When the temperature of the tribological assay is raised to $100^{\circ} \mathrm{C}$ (Fig. 7), several facts happen: (a) a new layer of iron phosphate is formed, confirming the previous results obtained for P (Table 4); (b) when $[\mathrm{BMP}]\left[\mathrm{NTf}_{2}\right]$ is used as an additive, the $\mathrm{FeOOH}$ is not present and seems to disappear from the surface; according to the area ratio, $\mathrm{FeOOH}$ seems to have been converted into $\mathrm{FePO}_{4}$ in the case of FLENI; (c) in the case of [Choline][NTf 2 , a fourth peak at $714.5 \mathrm{eV}$ is necessary for obtaining a good curve-fitting. However, it is difficult to assign this energy, although it can be related to $\mathrm{FeSO}_{4}$ (described at $713.6 \mathrm{eV}$ [52]) or $\mathrm{FeF}_{3}$ (described at 713.9-714.8 eV [53-55]). Neither $\mathrm{S}$ nor $\mathrm{F}$ could be detected in the sample. However, Fe2p3/2 is much more sensitive than F1s or S2p (iron is almost 2.5 times more sensitive than fluorine and six times more sensitive than sulphur) and the total amount is relatively low, thus sulphur or fluorine could be below the detection limit.

The chemical composition of the surface seems to be related to the friction coefficient (see Fig. 1). Friction coefficients for lubrication with FLENDER or FLENDER-IL mixtures at $40^{\circ} \mathrm{C}$ are very similar, as are the surfaces chemical composition (Fig. 6). When temperature rises to $100^{\circ} \mathrm{C},[\mathrm{BMP}]\left[\mathrm{NTf}_{2}\right]$ shows the lower friction coefficient, and this one is the only surface where iron hydroxy-oxides are not present 
(Fig. 7). Furthermore, FLENI-IL mixtures behave similarly. Although the chemical differences in Fe element are slight at $40^{\circ} \mathrm{C}$, it becomes evident that the lubricant with the lower friction coefficient at $100^{\circ} \mathrm{C}\left([\mathrm{BMP}]\left[\mathrm{NTf}_{2}\right]\right)$ is again the one generating a surface free of $\mathrm{FeOOH}$. These results seem to suggest that the presence of iron hydroxyl-oxides trends to increase the value of the friction coefficient. However, a straightforward correlation is difficult to stablish, as many other parameters as rheology are affecting friction.

On the other hand, it becomes hard to find a correlation between the surface composition and the wear volume (Fig. 3). However, results point somehow that, the higher the $\mathrm{Fe}_{\mathrm{Fe} 2 \mathrm{O} 3} / \mathrm{Fe}_{\mathrm{FeOOH}}$ ratio, the lower the wear volume. When the assay takes place at $40^{\circ} \mathrm{C}$, this ratio for $[$ Choline $]\left[\mathrm{NTf}_{2}\right]$ is the same using FLENDER or FLENI, and the volume scar is very similar in both cases. Furthermore, for [BMP] $\left[\mathrm{NTf}_{2}\right]$ and the neat oil the ratio is higher in FLENI than in FLENDER, and the wear volume is also lower using FLENI than FLENDER (Fig. 6). When checking the results at $100^{\circ} \mathrm{C}$ this behaviour seems more evident: the larger the wear volume, the lower the $\mathrm{Fe}_{\mathrm{Fe} 203} / \mathrm{Fe}_{\mathrm{FeOOH}}$ ratio (Fig. 6).

Subsequently, O1s high resolution spectra were also studied. Results are summarised in Figures 8 and 9. Unfortunately, the position for $\mathrm{O} 1 \mathrm{~s}$ in iron phosphate and iron hydroxy-oxides is almost overlapping (531.7 eV [50] for $\mathrm{FeOOH}$ and $531.8 \mathrm{eV}$ [56] for $\mathrm{FePO}_{4}$ ) and they cannot be easily identified. It can be seen also a new band between 533.0 and $533.6 \mathrm{eV}$ which is present in every sample and with more or less the same weight. This peak probably comes from an oxygen-containing chemical present in both gear oils.

The results for oxygen appear qualitatively consistent with those obtained for Fe2p3/2. It is difficult to evaluate a quantitative consistence as the oxidation state for the iron oxides could not be established.

Concerning the presence of $\mathrm{Fe}_{2}\left(\mathrm{SO}_{4}\right)_{3}$ in the surface for sample lubricated with [Choline][NTf $\left.{ }_{2}\right]$ in FLENI at $100^{\circ} \mathrm{C}$, the analysis of the $\mathrm{O} 1 \mathrm{~s}$ high resolution spectrum was not definitive since this compound is expected to appear at $531.6 \mathrm{eV}$ [57], thus overlapping with $\mathrm{FeOOH}$ and $\mathrm{FePO}_{4}$. 
FLENDER

1

2

3

4

5

6

7

8

9

10

11

12

13

14

15

16

17

18

19

20

21

22

23

24

25

26

27

28

29

30

31

32

33

34

35

36

37

38

39

40

41

42

43

44

45

46

47

48

49

50

51

52

53

54

55

56

57

58

59

60

61

62

63

64

65
FLENI

Ratio: 4.7/4.2/1

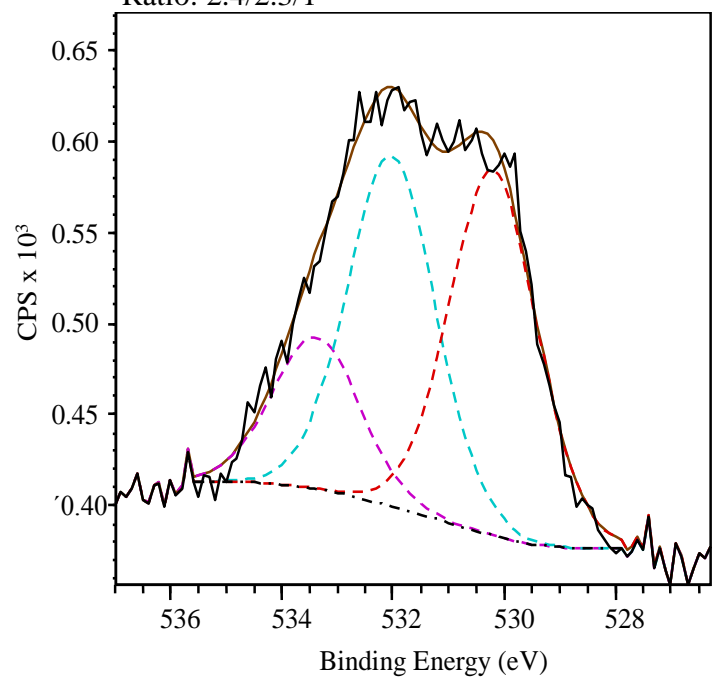

FLENDER+5\% [BMP][NTf $\left.\mathbf{N}_{2}\right]$

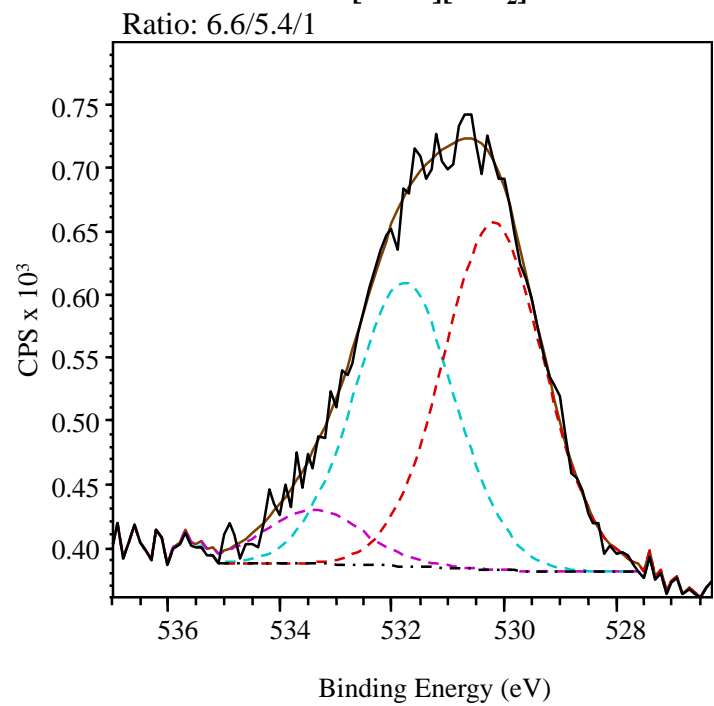

FLENDER+5\% [Choline] $\left[\mathbf{N T f}_{2}\right]$

Ratio: $1.8 / 2.3 / 1$

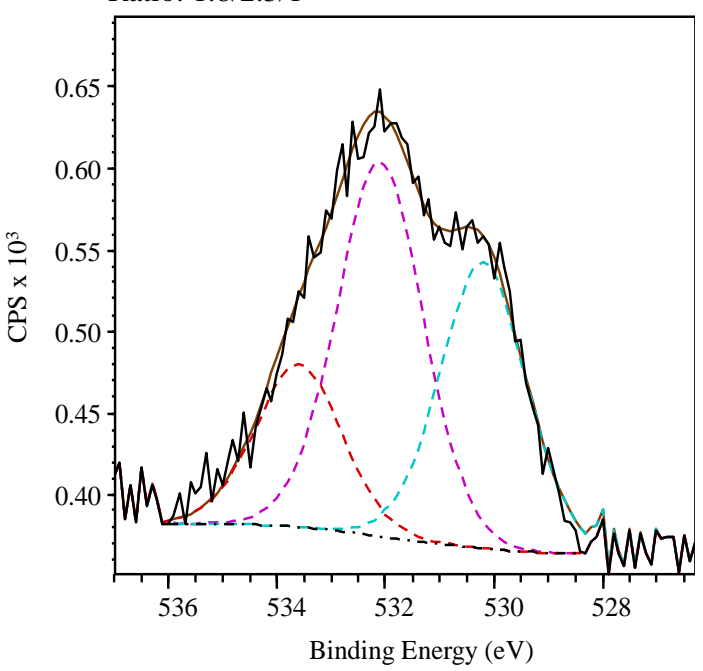

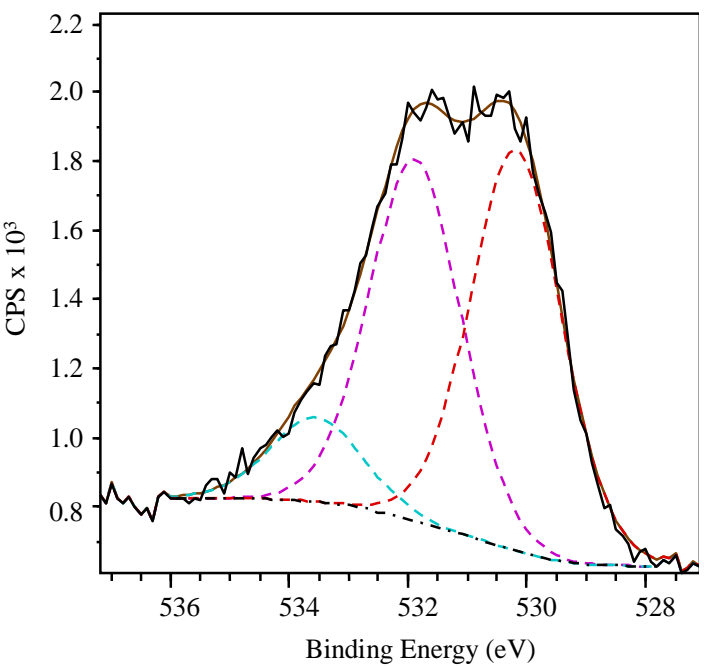

FLENI+5\% [BMP] $\left[\mathbf{N T f}_{2}\right]$

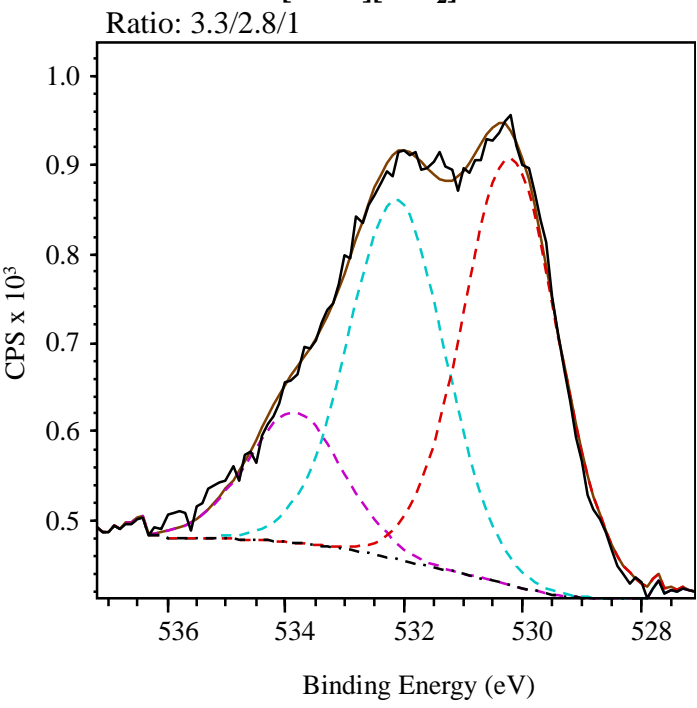

FLENI+5\% [Choline][NTf ${ }_{2}$ ]

Ratio: $3.2 / 2.4 / 1$

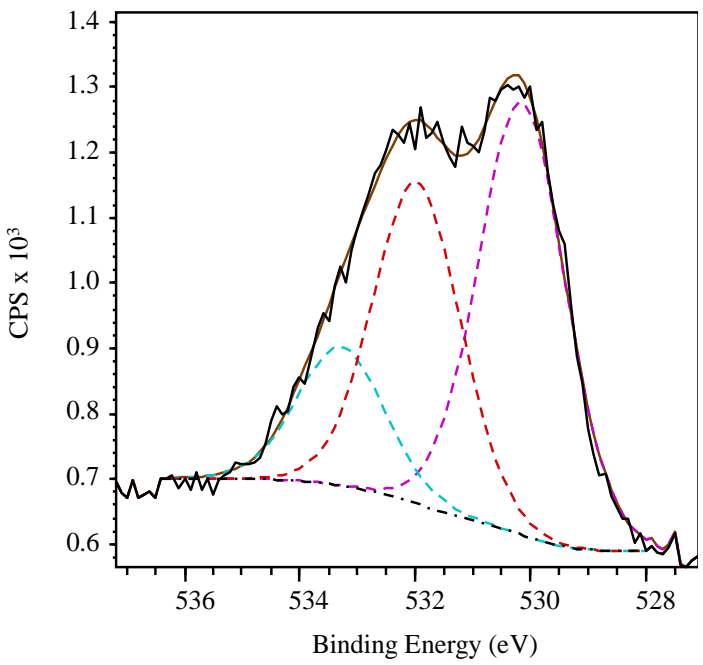

Fig. 8. Spectra with deconvoluted peaks of the $\mathrm{O} 1 \mathrm{~s}$ band for the different samples lubricated at $40^{\circ} \mathrm{C}$. Ratio is $\mathrm{Fe}_{2} \mathrm{O}_{3} / \mathrm{FeOOH} / \mathrm{FePO}_{4}$ areas ratio. 
FLENDER

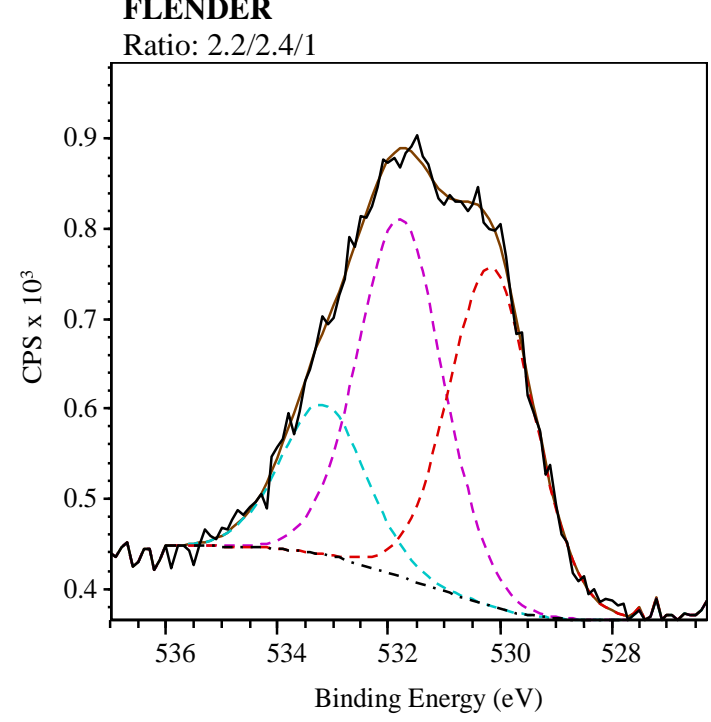

FLENDER+5\% [BMP][NTf f $\left._{2}\right]$

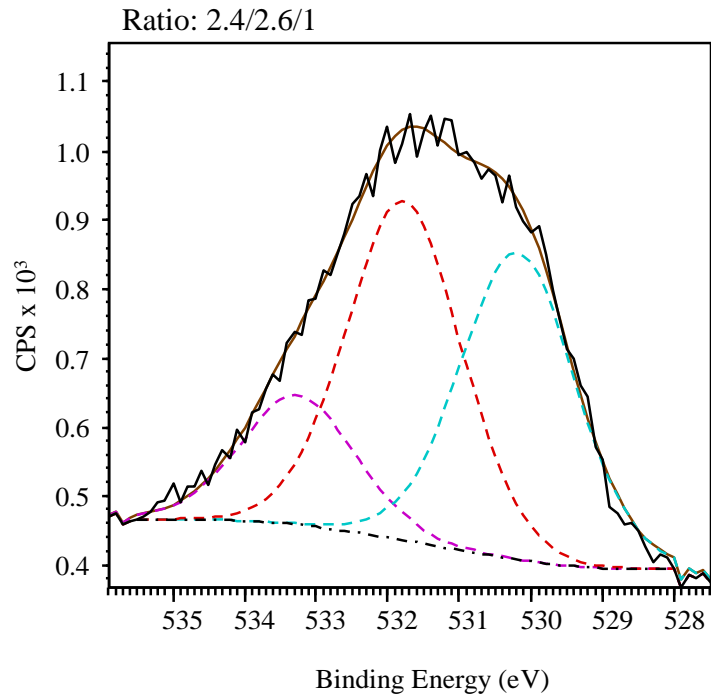

FLENDER+5\% [Choline][NTf $\left.{ }_{2}\right]$

Ratio: $2.2 / 2.1 / 1$

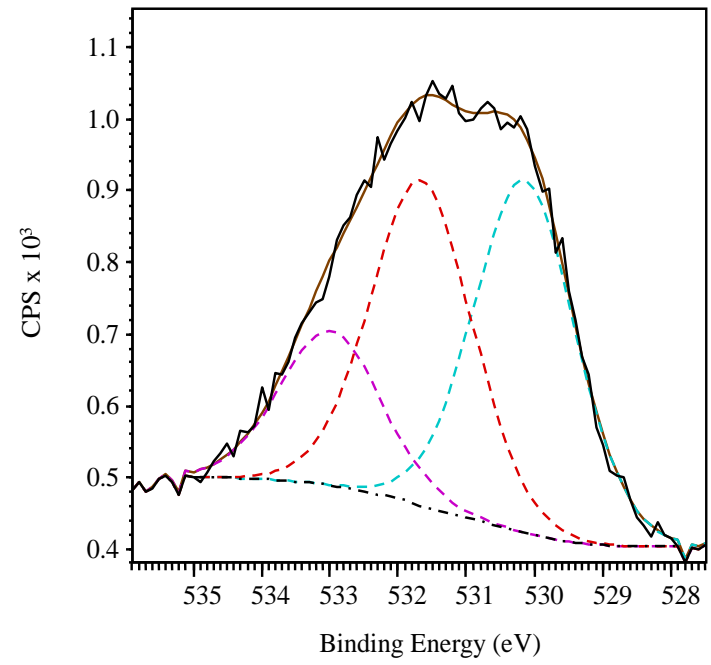

FLENI

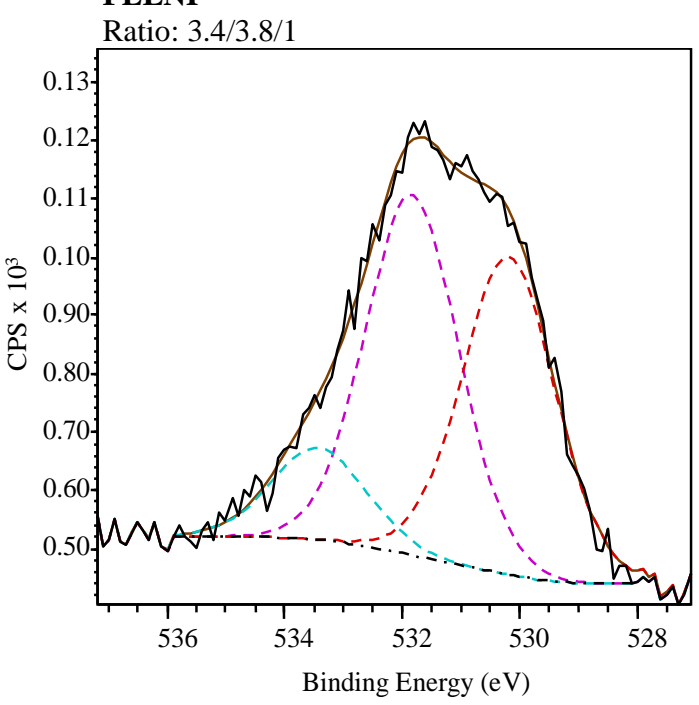

FLENI+5\% [BMP][NTf f $_{2}$

Ratio: 9.6/12/1

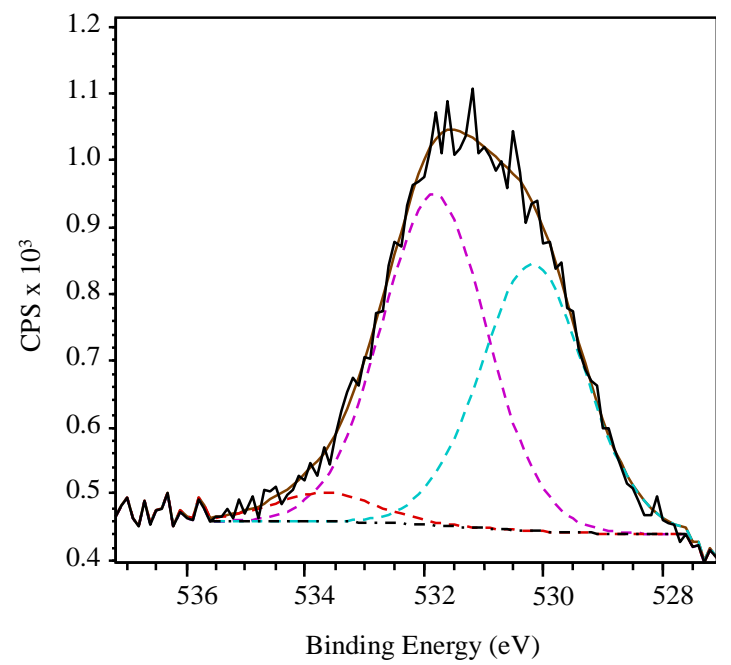

FLENI+5\% [Choline $]\left[\mathrm{NTf}_{2}\right]$

Ratio: $1.8 / 1.8 / 1$

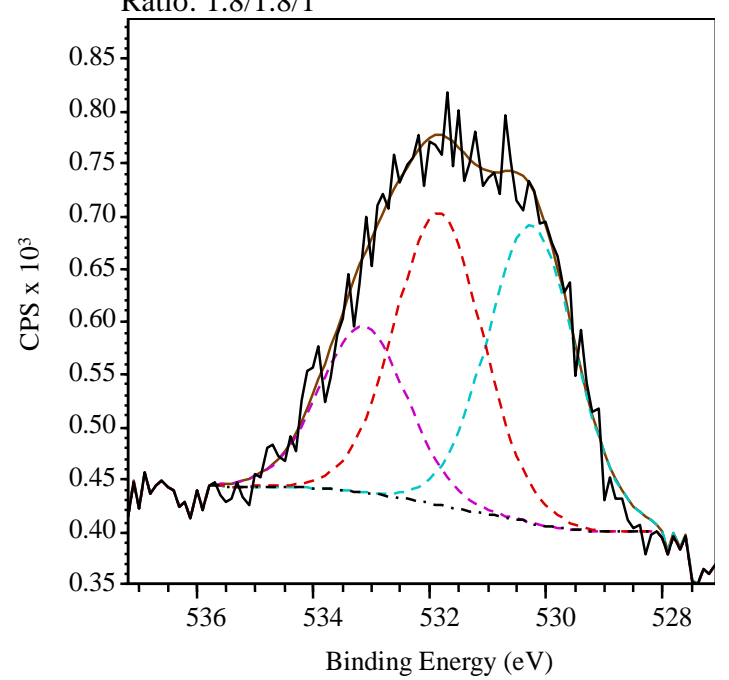

Fig. 9. Spectra with deconvoluted peaks of the $\mathrm{O} 1 \mathrm{~s}$ band for the different samples lubricated at $100^{\circ} \mathrm{C}$. Ratio is $\mathrm{Fe}_{2} \mathrm{O}_{3} / \mathrm{FeOOH} / \mathrm{FePO}_{4}$ areas ratio. 
Likewise, it is interesting to state the presence of an oxygen peak at $531.8 \mathrm{eV}$ for samples lubricated at $100^{\circ} \mathrm{C}$ with $[\mathrm{BMP}]\left[\mathrm{NTf}_{2}\right]$ regardless of the gear oil. Taking into account results for iron (shown in Fig. 7) no $\mathrm{FeOOH}$ is expected in these samples, so this peak results from phosphate. The area ratios indicate this fact since, according to the stoichiometry of the different compounds:

For $\mathrm{Fe}_{2} \mathrm{O}_{3} \quad \frac{\mathrm{O}_{\mathrm{Fe}_{2} \mathrm{O}_{3}}}{\mathrm{Fe}_{\mathrm{Fe}_{2} \mathrm{O}_{3}}}=\frac{3}{2}$

For $\mathrm{FeOOH} \quad \frac{O_{\mathrm{FeOOH}}}{\mathrm{Fe}_{\mathrm{FeOOH}}}=2$

For $\mathrm{FePO}_{4} \quad \frac{\mathrm{O}_{\mathrm{FePO}_{4}}}{\mathrm{Fe}_{\mathrm{FePO}_{4}}}=4$

And, therefore: $\frac{\mathrm{O}_{\mathrm{Fe}_{2} \mathrm{O}_{3}} / \mathrm{Fe}_{\mathrm{Fe}_{2} \mathrm{O}_{3}}}{\mathrm{O}_{\mathrm{FeO}_{4}} / \mathrm{Fe}_{\mathrm{FePO}_{4}}}=\frac{3 / 2}{4}=\frac{3}{8} \Rightarrow \frac{\mathrm{O}_{\mathrm{Fe}_{2} \mathrm{O}_{3}}}{\mathrm{O}_{\mathrm{FePO}_{4}}}=\frac{3}{8} \cdot \frac{\mathrm{Fe}_{\mathrm{Fe}_{2} \mathrm{O}_{3}}}{\mathrm{Fe}_{\mathrm{FePO}_{4}}}$

If the ratio of areas $\mathrm{Fe}_{\mathrm{Fe} 2 \mathrm{O} 3} / \mathrm{Fe}_{\mathrm{FePO} 4}$ is evaluated, values are obtained of 2.7 for FLENDER and 2.6 for FLENI. Therefore, $\mathrm{O}_{\mathrm{Fe} 2 \mathrm{O} 3} / \mathrm{O}_{\mathrm{FePO} 4}$ is expected to be 2.7 $(3 / 8)=1.01$ (for FLENDER) and 2.6 $(3 / 8)=0.98$ (for FLENI) and their measured values are 0.92 and 0.80 , quite close to the expected ones.

\section{Conclusions}

The use of $[\mathrm{BMP}]\left[\mathrm{NTf}_{2}\right]$ and $[$ Choline $]\left[\mathrm{NTf}_{2}\right]$ ionic liquids as an additive within two fully formulated wind turbine gearbox oils were studied under different test conditions. These results led to the following conclusions:

- The gear oils tribological performance decreased as expected when the severity of the test conditions increased (higher load or temperature); this deterioration of performance occurred even with the reaction of the active components present within the additive package on the surface.

- The addition of both ionic liquids did not significantly change friction behavior, however wear performance of the gear oils (FLENI and FLENDER) improved under all test conditions even with no detection via EDS of sulphur or phosphorus reaction with the surface.

- $[\mathrm{BMP}]\left[\mathrm{NTf}_{2}\right]$ showed improved wear reducing properties as an additive in comparison with [Choline][ $\left.\mathrm{NTf}_{2}\right]$. 
- The surface analysed with XPS confirms the enhanced quality of $[\mathrm{BMP}]\left[\mathrm{NTf}_{2}\right]$ compared to $[$ Choline $]\left[\mathrm{NTf}_{2}\right]$ taking into account the presence of iron phosphates; XPS points also to a correlation between the ratio of iron oxides / iron hydroxy-oxides and the wear volume, suggesting that the hydroxy-oxides contribute to worsen the lubrication; in addition, the chemical mechanism of lubrication depends on the temperature. At $40^{\circ} \mathrm{C}$ the presence of ionic liquids tends to increase the ratio of iron oxides / iron hydroxy-oxides resulting in a higher percentage of wear reduction of the mixtures with regard to the gear oils; but at $100^{\circ} \mathrm{C}$ the ratio of iron oxides / iron hydroxy-oxides of the mixtures is only slightly higher than that of the gear oils and the percentage of wear reduction is lower.

\section{Acknowledgements}

The authors wish to express their thanks to the Ministry of Science and Innovation Spain and to the FICYT (the Foundation for the promotion in Asturias of the Applied Scientific Research and Technology) for supporting this research within the framework of the Research Projects WINDTRIB (DPI2010-18166) and GRUPIN14-023, respectively. They also thank the University of Oviedo for funding the research stay of Raquel Monge at Southampton University and the support of Imperial College London in the viscosity measurements. Similarly, they thank the Ministry of Education, Culture and Sport for funding, within the program "José Castillejo", the research stay of José Luis Viesca at Bournemouth University. The Unit of Photoelectron, UV-Vis and FTIR spectroscopy from the Scientific-Technical Services at the University of Oviedo is also acknowledged.

\section{References}

[1] P.M.T. Marques, C.M.C.G. Fernandes, R.C. Martins, J.H.O. Seabra, Efficiency of a gearbox lubricated with wind turbine gear oils, Tribol. Int. 71 (2014) 7-16.

[2] C.M.C.G. Fernandes, R.C. Martins, J.H.O. Seabra, Torque loss of type C40 FZG gears lubricated with wind turbine gear oils, Tribol. Int. 70 (2014) 83-93.

[3] C.M.C.G. Fernandes, R.C. Martins, J.H.O. Seabra, Friction torque of thrust ball bearings lubricated with wind turbine gear oils, Tribol. Int. 58 (2013) 47-54.

[4] C.M.C.G. Fernandes, R.C. Martins, J.H.O. Seabra, Friction torque of cylindrical roller thrust bearings lubricated with wind turbine gear oils, Tribol. Int. 59 (2013) 121-128. 
[5] C.M.C.G. Fernandes, P.M.P. Amaro, R.C. Martins, J.H.O. Seabra, Torque loss in thrust ball bearings lubricated with wind turbine gear oils at constant temperature, Tribol. Int. 66 (2013) 194-202.

[6] C.M.C.G. Fernandes, P.M.P. Amaro, R.C. Martins, J.H.O. Seabra, Torque loss in cylindrical roller thrust bearings lubricated with wind turbine gear oils at constant temperature, Tribol. Int. 67 (2013) 72-80.

[7] V. Totolin, I. Minami, Ch. Gabler, N. Dörr, Halogen-free borate ionic liquids as novel lubricants for tribological applications, Tribol. Int. 67 (2013) 191-198.

[8] S. Stolte, S. Steudte, O. Areitioaurtena, F. Pagano, J. Thöming, P. Stepnowski, A. Igartua, Ionic liquids as lubricants or lubrication additives: An ecotoxicity and biodegradability assessment, Chemosphere 89 (2012) 1135-1141.

[9] C.F. Ye, W.M. Liu, Y.X. Chen, L.G. Yu, Room-temperature ionic liquids: a novel versatile lubricant, Chem. Commun. 10 (2001) 2244-2245.

[10] H. Kamimura, T. Kubo, I. Minami, S. Mori, Effect and mechanism of additives for ionic liquids as new lubricants, Tribol. Int. 40 (2007) 620-625.

[11] L.J. Weng, X.Q. Liu, Y.M. Liang, Q.J. Xue, Effect of tetraalkylphosphonium based ionic liquids as lubricants on the tribological performance of a steel-on-steel system, Tribol. Lett. 26 (2007) 11-17.

[12] A.E. Jimenez, M.D. Bermudez, Ionic liquids as lubricants of titanium-steel contact. Part 2: Friction, wear and surface interactions at high temperature, Tribol. Lett. 37 (2010) 431-443.

[13] A.E. Jimenez, M.D. Bermudez, Ionic liquids as lubricants for steel-aluminum contacts at low and elevated temperatures, Tribol. Lett. 26 (2007) 53-60.

[14] A.E. Jimenez, M.D. Bermudez, Imidazolium ionic liquids as additives of the synthetic ester propylene glycol dioleate in aluminium-steel lubrication. Wear 265 (2008) 787-798.

[15] H. Kondo, Protic ionic liquids with ammonium salts as lubricants for magnetic thin film media, Tribol. Lett. 31 (2008) 211-218.

[16] I. Minami, M. Kita, T. Kubo, H. Nanao, S. Mori, The tribological properties of ionic liquids composed of trifluorotris(pentafluoroethyl) phosphate as a hydrophobic anion, Tribol. Lett. 30 (2008) 215-223.

[17] S.D.A. Lawes, S.V. Hainsworth, P. Blake, K.S. Ryder, A.P. Abbott, Lubrication of steel/steel contacts by choline chloride ionic liquids, Tribol. Lett. 37 (2010) 103-110. 
[18] J.L. Viesca, A. Hernández Battez, R. González, T. Reddyhoff, A. Torres Pérez, H.A. Spikes, Assessing boundary film formation of lubricant additivised with 1-hexyl-3-methylimidazolium tetrafluoroborate using ECR as qualitative indicator, Wear 269 (2010) 112-117.

[19] A. Hernández Battez, R. González, J.L. Viesca, D. Blanco, E. Asedegbega, A. Osorio, Tribological behaviour of two imidazolium ionic liquids as lubricant additives for steel/steel contacts, Wear 266 (2009) 1224-1228.

[20] D. Blanco, R. González, A. Hernández Battez, J.L. Viesca, A. Fernández-González, Use of ethyldimethyl-2-methoxyethylammonium tris(pentafluoroethyl)trifluorophosphate as base oil additive in the lubrication of TiN PVD coating, Tribol. Int. 44 (2011) 645-650.

[21] R. González, A. Hernández Battez, D. Blanco, J.L. Viesca, A. Fernández-González, Lubrication of TiN, CrN and DLC PVD Coatings with 1-Butyl-1-Methylpyrrolidinium tris(pentafluoroethyl)trifluorophosphate, Tribol. Lett. 40 (2010) 269-277.

[22] D. Blanco , A. Hernández Battez, J.L. Viesca, R. González, A. Fernández-González, Lubrication of CrN Coating With Ethyl-Dimethyl-2-Methoxyethylammonium Tris(pentafluoroethyl) Trifluorophosphate Ionic Liquid as Additive to PAO 6, Tribol. Lett. 41 (2011) 295-302.

[23] R. González, A. Hernández Battez, J.L. Viesca, A. Higuera-Garrido, A. Fernández-González, Lubrication of DLC coatings with two tris(pentafluoroethyl)trifluorophosphate anion-based ionic liquids, Tribol. Trans. 56 (2013) 887-895.

[24] A. Hernández Battez, R. González, J.L. Viesca, A. Fernández-González, M. Hadfield, Lubrication of PVD coatings with ethyl-dimethyl-2-methoxyethylammonium tris(pentafluoroethyl)trifluorophosphate, Tribol. Int. 58 (2013) 71-78.

[25] J.L. Viesca, A. García, A. Hernández Battez, R. González, R. Monge, A. Fernández-González, M. Hadfield, FAP ${ }^{-}$Anion Ionic Liquids Used in the Lubrication of a Steel-Steel Contact, Tribol. Lett. 52 (2013) 431-437.

[26] A. García, R. González, A. Hernández Battez, J.L. Viesca, R. Monge, A. Fernández-González, M. Hadfield, Ionic liquids as a neat lubricant applied to steel-steel contacts, Tribol. Int. 72 (2014) 4250.

[27] J. Qu, J.J. Truhanb, S. Daic, H. Luod, P.J. Blau, Ionic liquids with ammonium cations as lubricants or additives, Tribol. Lett. 22 (2006) 207-214. 
[28] C. Yao, W.R. Pitner, J.L. Anderson, Ionic Liquids Containing the

Tris(pentafluoroethyl)trifluorophosphate Anion: a New Class of Highly Selective and Ultra Hydrophobic Solvents for the Extraction of Polycyclic Aromatic Hydrocarbons Using Single Drop Microextraction, Anal Chem. 81 (2009) 5054-5063.

[29] F. Zhou, Y.M. Liang, W.M. Liu, Ionic liquid lubricants: designed chemistry for engineering applications, Chem. Soc. Rev. 38 (2009) 2590-2599.

[30] I. Minami, Ionic liquids in tribology, Molecules 14 (2009) 2286-2305.

[31] M. Palacio, B. Bhushan, A review of ionic liquids for green molecular lubrication in nanotechnology, Tribol. Lett. 40 (2010) 247-268.

[32] M.D. Bermúdez, A.E. Jiménez, J. Sanes, F.J. Carrión, Ionic liquids as advanced lubricant fluids, Molecules 14 (2009) 2888-2908.

[33] J. Qu, H. Luo, M. Chi, Ch. Ma, P.J. Blau, S. Dai, M.B. Viola, Comparison of an oil-miscible ionic liquid and ZDDP as a lubricant anti-wear additive, Tribol. Int. 71 (2014) 88-97.

[34] G. Mordukhovich, J. Qu, J.Y. Howe, S. Bair, B. Yu, H. Luo, Smolenski DJ, Blau PJ, Bunting BG, Dai S. A low-viscosity ionic liquid demonstrating superior lubricating performance from mixed to boundary lubrication, Wear 301 (2013) 740-746.

[35] J. Qu, P.J. Blau, S. Dai, H. Luo, H.M. Meyer III, Ionic Liquids as Novel Lubricants and Additives for Diesel Engine Applications, Tribol. Lett. 35 (2009) 181-189.

[36] J. Qu, D.G. Bansal, B. Yu, J.Y. Howe, H. Luo, S. Dai, H. Li, P.J. Blau, B.G. Bunting, G. Mordukhovich, D.J. Smolenski, Antiwear Performance and Mechanism of an Oil-Miscible Ionic Liquid as a Lubricant Additive, ACS Appl. Mater. Interfaces 4 (2012) 997-1002.

[37] A. Greco, K. Mistry, V. Sista, O. Eryilmaz, A. Erdemir, Friction and wear behaviour of boron based surface treatment and nano-particle lubricant additives for wind turbine gearbox applications, Wear 271 (2011) 1754-1760

[38] Y. Bo, D. G. Bansal, J. Qu, X. Sun, H. Luo, S. Dai, P. J. Blau, B. G. Bunting, G. Mordukhovich, D. J. Smolenski, Oil-miscible and non-corrosive phosphonium-based ionic liquids as candidate lubricant additives, Wear 289 (2012) 58-64.

[39] D. Li, M. Cai, D.Feng, F. Zhoun , W. Liu, Excellent lubrication performance and superior corrosion resistance of vinyl functionalized ionic liquid lubricants at elevated temperature, Tribol. Int. 44 (2011) 1111-1117. 
[40] D.A.Shirley, High-resolution X-ray photoemission spectrum of the valence bands of gold, Phys. Rev. B 5 (1972) 4709-4714.

[41] E.R. Åberg, A.G.T. Gustavsson, Design and evaluation of modified simplex methods, Anal Chim. Acta 144 (1982) 39-53.

[42] J.E. Fernández Rico, A. Hernández Battez, D. García Cuervo, Wear prevention characteristics of binary oil mixtures, Wear 253 (2002) 827-831.

[43] A. Cambiella, J.M. Benito, C. Pazos, J. Coca, A. Hernández, J.E. Fernández, Formulation of emulsifiable cutting fluids and extreme pressure behavior, J. Mater Process. Technol. 184 (2007) $139-145$.

[44] M. Yao, Y. Liang, Y. Xia, F. Zhou, Bisimidazolium Ionic Liquids as the High-Performance Antiwear Additives in Poly(ethylene glycol) for Steel-Steel Contacts, App. Mater \& Interfaces $1(2009) 467-471$.

[45] I. Otero, E.R. López, M. Reichelt, J. Fernández, Friction and anti-wear properties of two tris(pentafluoroethyl)trifluorophosphate ionic liquids as neat lubricants, Tribol. Int. 70 (2014) 104111.

[46] I.D. Welsh, M.A. Sherwood, Photoemission and electronic structure of FeOOH: Distinguishing between oxide and oxyhydroxide, Phys. Rev. B 40 (1989) 6386-6392.

[47] B.J. Tan, K.J. Klabunde, P.M.A. Sherwood, X-ray photoelectron spectroscopy studies of solvated metal atom dispersed catalysts. Monometallic iron and bimetallic iron-cobalt particles on alumina, Chem. Mater. 2 (1990) 186-191.

[48] V.I. Nefedov, Y.V Salyn, A comparison of different spectrometers and charge corrections used in Xray photoelectron spectroscopy, J. Electron. Spectrosc. Relat. Phenom. 10 (1977) 121-124.

[49] H. Konno, M. Nagayama, X-ray photoelectron spectra of hexavalent iron, J. Electron Spectrosc. \& Relat. Phenom. 18 (1980) 341-343.

[50] N.S. McIntyre, D.G. Zetaruk, X-ray photoelectron spectroscopic studies of iron oxides, Anal Chem. 49 (1977) 1521-1529.

[51] V.V. Nemoshkalenko, V.V. Didyk, V.P. Krivitskii, A.I. Senekevich, Investigation of the atomic charges in iron, cobalt and nickel phosphides, Zh Neorg Khimii 28 (1983) 2182-2192.

[52] R.V. Siriwardene, J.M Cook, Interactions of $\mathrm{SO}_{2}$ with sodium deposited on silica, J. Colloid Interface Sci. 108 (1985) 414-422. 
[53] D.D. Hawn, B.M. DeKoven, Deconvolution as a correction for photoelectron inelastic energy losses in the core level XPS spectra of iron oxides, Surf. Interface Anal. 10 (1987) 63-74.

[54] J.C. Carver, G.K. Schweitzer, T.A. Carlson, Use of X-ray photoelectron spectroscopy to study bonding in Cr, Mn, Fe, and Co compounds, J. Chem. Phys. 57 (1972) 973-982.

[55] M. Kasrai, D.S Urch, Electronic structure of iron (II) and (III) fluorides using X-ray emission and Xray photoelectron spectroscopies, J. Chem. Soc. Faraday Trans, II 75 (1979) 1522-1531.

[56] Y. Barbaux, M. Dekiouk, D. Le Maguer, L. Gengembre, D. Huchette, J. Grimblot, Bulk and surface analysis of a Fe-P-O oxydehydrogenation catalyst, Appl. Catalysis A 90 (1992) 51-60.

[57] B.J. Lindberg, K. Hamrin, G. Johansson, U. Gelius, A. Fahlmann, C. Nordling, K. Siegbahn, Molecular Spectroscopy by Means of ESCA II. Sulfur compounds. Correlation of electron binding energy with structure, Phys. Scripta 1 (1970) 286-298. 


\section{P.J. Blau and P.H. Shipway}

Wear. Co-Editors-in-Chief

Gijon, Spain, October $9^{\text {th }}, 2014$

Title: Ionic liquids as an additive in fully formulated wind turbine gearbox oils

Authors: R. Monge, R. González, A. Hernández Battez, A. Fernández-González, J.L. Viesca, A. García, M. Hadfield

\section{Highlights}

- Two [NTf2] anion-based ionic liquids as additives in fully formulated gearbox oils.

- Ionic liquids used as an additive at $5 \mathrm{wt} \%$ have a slight friction modifier character.

- Wear performance of the gear oils has been improved under all test conditions.

- Chemical mechanism of lubrication depends on the temperature.

Sincerely yours,

Rubén González Rodríguez 